\begin{tabular}{|l|l|c|c|l|c|l|}
\hline \multirow{2}{*}{ SPi } & ECIN & ECIN_12515 & $\mathbf{B}$ & Dispatch: September 13, 2017 & Journal: ECIN & CE: \\
\cline { 2 - 6 } & Journal Name & Manuscript No. & $\mathbf{D}$ & Author Received: & No of pages: 27 & TS: David \\
\hline
\end{tabular}

\title{
DOES DELEGATION INCREASE WORKER TRAINING?
}

CHRISTOS BILANAKOS, JOHN S. HEYWOOD, JOHN G. SESSIONS and NIKOLAOS THEODOROPOULOS*

We model a principal-firm offering training to its agent worker under two alternative organizational structures: integration, where the principal retains authority to overrule the investment project recommended by the worker; and delegation, where the principal cannot overrule the worker's preferred investment project. We assume that training reduces the worker's effort cost of assembling information about alternative projects' payoffs and identify the conditions under which delegation increases the profitmaximizing intensity of training. Empirical estimates from matched employer-employee data show that workplaces delegating authority do provide more worker training. This result persists in two cross sections, in panel fixed-effect estimates and, critically, in an instrumental variable exercise that also controls for establishment fixed effects. (JEL D21, D22, D23, M53, M54)

\section{INTRODUCTION}

Delegation of decision-making allows employers to capture the superior knowledge and information of workers. The objective functions of workers, however, may differ sharply from those of their employers. This tradeoff between enhanced information and misaligned incentives lies at the heart of a growing literature claiming that delegation and incentives are

*We acknowledge the Department of Trade and Industry, the Economic and Social Research Council, the Advisory, Conciliation and Arbitration Service and the Policy Studies Institute as the originators of the Workplace Employee Relations Survey data, and the Data Archive at the University of Essex as the distributor of the data. None of these organizations bears any responsibility for our analysis or interpretation. We thank participants of the 20th Colloquium of Personnel Economics (COPE, Zurich) and seminar attendees at the University of Crete. We also thank the associate editor and two anonymous referees.

Bilanakos: Department of International and European Economic Studies, Athens University of Economics and Business, Athens, 10434, Greece. Phone +30 6939694996, Fax +30 2106987459, E-mail xmpilan@ aueb.gr

Heywood: Distinguished Professor, Department of Economics, University of Wisconsin-Milwaukee, Milwaukee, WI 53211, Phone (414) 229-4310, Fax (414) 229-5915, E-mail heywood@uwm.edu

Sessions: Professor of Economics, Department of Economics and IZA, University of Bath, Bath, BA27AY, UK. Phone (44) 1225 384517, Fax (44)1225 383423, E-mail j.g.sessions@bath.ac.uk

Theodoropoulos: Assistant Professor of Economics, Department of Economics, University of Cyprus, Nicosia, CY-1678, Cyprus. Phone 00357-22893715, Fax 0035722895028, E-mail n.theodoropoulos@ucy.ac.cy complementary - the more authority delegated to workers, the stronger must be the incentives for workers to align their objectives with those of their employer.

We uniquely provide a theoretical illustration and supporting empirical evidence showing that delegation increases employee training. We extend Aghion and Tirole's (1997) seminal model to recognize that a worker's effort cost of acquiring superior information can be reduced through the provision of training. We compare the profitmaximizing training intensity under two alternative organizational structures: integration, where the firm retains the ability to overrule the investment project recommended by the worker; and delegation, where the firm cannot overrule the worker's preferred investment project.

Our model predicts that the firm provides more training under delegation than under integration if the preferences of the firm and the worker are sufficiently congruent. This reflects the key trade-off from delegation. The worker is induced to supply more effort in acquiring information but the firm loses control and risks its preferred investment project not being implemented. When the firm

\section{ABBREVIATIONS}

COPE: Colloquium of Personnel Economics

IV: instrumental variable

OLS: XXX

PRP: XXX

2SLS: Two-Stage Least Squares

WERS: Workplace Employment Relations Surveys 
1 benefits similarly from its own preferred project

and from that of the worker, the effort-enhancing effect of delegation dominates the loss-of-control effect and this makes additional training a profitable investment.

In an Appendix, we add training to a richer model in which incentive pay is also an option to foster the agent's effort. We again show that training can be a profitable investment under delegation and partially characterize the optimal intensity of training, wage incentives and effort under each authority structure (integration and delegation), while leaving the full treatment of the relationship between these variables for future research.

We impose delegation or integration exogenously in our model. This seems appropriate in situations where, for example, more senior management may require certain types of delegation, or where an external hire imposes delegation practices in a way that is unrelated to the firms' training practices. There may also be structural differences across industries that make delegation more likely - something we exploit in our instrumental variable (IV) strategy in Section V.C. Within this framework, our nonequilibrium approach of looking at integration and delegation separately provides a sensible and testable association between delegation and training.

We test the prediction of our theoretical model using large British matched employer-employee cross sections and an associated panel. We find that those establishments which delegate more, with workers greatly influencing their own tasks, offer more training. This persists across a variety of specifications, alternative sample restrictions and using alternative definitions of both delegation and training. It persists in establishment fixed-effect estimates, under alternative functional forms and in reasonable IV estimates that also control for workplace fixed effects. ${ }^{1}$ The empirical relationship between delegation and training appears remarkably durable.

Our investigation remains pertinent as delegation and decentralization of decision-making within firms have become increasingly common since the late 1970s, being most evident in Scandinavian and Anglo-Saxon countries (Aghion, Bloom, and VanReenen 2014). ${ }^{2}$ This growth in

1. We refer to the terms "firm," "workplace," and "establishment" interchangeably throughout the paper.

2. Empirical studies discussing the growth of delegation and its consequences include Osterman (1994), Caroli, Greenan, and Guellec (2001), and Rajan and Wulf (2006). actual delegation has been matched by a recent literature on the relationship between incentives and delegation, which we summarize in the next section.

In what follows, Section II sets our study in the context of related literature. Section III provides the theoretical framework and identifies the conditions under which delegation increases training. Section IV discusses the data and empirical methodology. Section V presents empirical results and provides robustness checks. Section VI concludes and offers suggestions for further research.

\section{RELATED LITERATURE}

Our research fits a strand of literature that models pairs of human resource practices searching for complements or substitutes - see, for example, Allgulin and Éllingsen (2002). This allows more tractable theoretical models and cleaner empirical predictions. ${ }^{3}$ We examine the pair of delegation and training. The study of these practices has generated two extensive but distinct literatures. To our knowledge, we are the first to examine delegation of authority as a determinant of training.

In this section, we briefly review the research on delegation and incentives that we extend to include the training decision. Theoretical work views the choice of delegation in terms of information and control. Delegating authority can be beneficial because workers know more about their day-to-day tasks than their employer. Yet, workers' objectives can differ from those of their employer. This tradeoff between information and objectives exists because the agent does not fully communicate private information when the principal retains authority. This arises because of bounded rationality (Jensen and Meckling 1992) or because of the agent's strategic use of information (Holmstrom 1984).

Grossman and Hart (1986) observe that authority might follow from a contract that allocates decision rights within the organization (see also Hart and Moore 1990). Such formal authority, however, does not always coincide with real authority, the effective control over decisionmaking. Aghion and Tirole (1997)- hereafter

3. Another strand of the literature investigates how a comprehensive collection of human resource practices influences productivity. This literature is uniformly empirical - see, for example, Ichniowski, Shaw, and Prennushi (1997). 
AT - explore this tension between real and formal authority and its implications for delegation. They recognize that information provision can be a critical yet noncontractible relation-specific investment.

AT model a principal-firm and an agentworker who together implement a single investment project. The firm tasks the worker with assembling information regarding the expected payoffs across an array of potential projects. The firm selects from two alternative organizational structures: integration, whereby the firm maintains formal authority over investment decisions and can ignore the worker's recommendation as to the "best" investment project; and delegation, whereby the worker selects a particular project and cannot be overruled. AT show that delegating authority encourages the worker to work harder in ascertaining which project should be implemented. However, this higher effort comes with a loss of control and an increased likelihood that the chosen project fails to maximize the firm's payoff. Which effect dominates depends upon how congruent are the objectives of the firm and worker. The less their objectives coincide, the more likely will the loss of control effect dominate and the more likely will the firm retain formal authority.

We expand AT by imagining that the firm can invest in training. This training lowers the cost of information acquisition by the worker and makes delegation particularly effective in providing superior information. We show that this is a profitable investment when objectives are sufficiently congruent.

Several papers have, like us, developed extensions to AT's framework. Baker, Gibbons, and Murphy (1999) argue that even though delegation can only ever be informal, it might remain in equilibrium due to reputational concerns. Hart and Holmstrom (2010) and Bolton and Dewatripont (2013) also stress that delegation may persist despite the typical ability of the principal to reverse a delegation decision. Zabojnik (2002) argues that it is less costly to motivate an agent to work on their own project rather than on the principal's project, while De Paola and Scoppa (2006) investigate the costs and benefits of delegation within a framework where the principal cannot observe the agent's effort. In both cases, delegation persists as a feasible outcome when the loss of control implied by delegation proves less costly for the principal than the loss of information under centralization. $^{4}$

Estimation by Aghion, Bloom, and VanReenen (2014) confirms that the congruence of preferences (as proxied by trust) helps determine delegation. Itoh, Kikutani, and Hayashida (2008) show that delegation from core to affiliated Japanese firms is associated with incentives for accountability. Nagar (2002), Colombo and Delmastro (2004), Foss and Laursen (2005) and De Varo and Kurtulus (2010) demonstrate that incentive payments for managers and for workers are associated with delegation. Yet, De Varo and Prasad (2015) argue that noisy incentive pay may induce risk-averse agents to select suboptimal tasks. For instance, surgeons may not operate on high-risk patients. They confirm that delegation and incentives are positively correlated for simple jobs but negatively correlated for complex jobs (where task selection is valuable). Lo et al. (2016) show that sales employees with higher tenure and skills are delegated more pricing authority even as uncertain product markets make delegation less likely.

While the evidence is not monolithic, we incorporate the issues of these studies into our testing. In robustness checks, we examine whether the influence of delegation on training varies with the presence of incentive schemes. If incentive schemes facilitate delegation by increasing the congruence of interests, they may also make training more valuable to the firm. Put differently, training becomes more profitable when it is more likely to be used in the interest of the firm. We will also experiment with the role of an uncertain market environment.

As a last note, delegation may simply be critical for firm success. Bloom, Sadun, and VanReenen (2012b) show that failure to delegate authority (often resulting from lack of trust) impedes firm growth. Boedker et al. (2011) find that of 32 practices, delegation correlates most closely with their "High Performing Workplace Index." More generally, researchers emphasize that appropriate delegation reflects successful management (Garicano

4. Bester and Krahmer (2008) also vary AT by modeling a situation in which the agent's job is to complete rather than to identify a project, showing that delegation becomes less attractive in this case. In another extension, Stein (2002) argues that delegation is most likely to dominate when information is "soft" - that is, not verifiable. Relatedly, Dessein (2002) builds a model with asymmetric information to show that delegation might be the most efficient way for the principal to extract the agent's private knowledge on projects' payoffs. 
and Rayo 2016) and generates productivity differences across firms and countries (Bloom et al. 2012a). As a consequence, we adopt an empirical strategy that tries to rule out threats to the independent role that we argue delegation can play. We want to avoid presenting correlations that simply reflect that superior management more likely both delegates and trains workers.

We use matched employer-employee data to estimate the determinants of firm-sponsored training. Such estimates frequently focus on the role of competition in labor and product markets (Acemoglu and Pischke 1998, 1999; Manning 2003). ${ }^{5}$ While Brunello and Gambarotto (2007) confirm that employers provide less training in more competitive labor markets, Bilanakos et al. (2017) find that product market dominance strengthens investment in training. We will account for such determinants when focusing on the role of delegation. We are aware of no papers that relate training to delegation and only one paper that relates (exogenous) human capital to the degree of delegation within a firm. ${ }^{6}$ While building from these previous works, we test whether the delegation of decision-making authority plays an independent role in an establishment's choice of training intensity.

\section{THEORETICAL MODEL}

\section{A. Setup}

We consider a principal-owner, $\mathrm{P}$, and an agent-employee, A, who either implement a single investment project or choose to do nothing. $\mathrm{P}$ tasks A with collecting information about the payoffs of $n>3$ potential and a priori ostensibly identical projects. The principal's gross profit associated with each project $k \in\{1,2, \ldots, n\}$ is $B_{k}$ and the agent's corresponding private benefit (which may include on-the-job perks or the possibility of signaling his ability) is $b_{k}$. These payoffs

5. For empirical evidence on the determinants of firmsponsored general training see, for example, Katz and Ziderman (1990), Krueger (1993), Acemoglu and Pischke (1998), and Booth and Bryan (2005).

6. De Paola and Scoppa (2006) argue that delegation, thanks to on-the-job learning and the possible expropriation of resources, might well increase an agent's outside option. This increase, in turn, might increase the quit propensity of the agent and thus the turnover costs of the firm. Thus, firms should be less likely to delegate the higher are turnover costs and the lower the degree of firm specific human capital. do not take into account any wage payments from $\mathrm{P}$ to $\mathrm{A}$. The case where $\mathrm{P}$ and $\mathrm{A}$ do nothing is summarized in a "project zero" yielding payoffs $B_{0}=b_{0}=0 .^{7}$ The principal reaps $B>0$ from her preferred project while the agent reaps $b>0$ from his own preferred project. The agent's benefit from P's preferred project is $\beta b$ and the principal's profit from $A$ 's preferred project is $\alpha B$, where $a, \beta \in(0,1]$ are exogenous congruence parameters.

The principal chooses the level of training, $I$, to provide the agent. The training cost incurred by $\mathrm{P}$ is $c(I)$ with $c^{\prime}(0)=0, c^{\prime}(I)>0$ and $c^{\prime \prime}(I)>0$ for $I>0$. Both the principal and the agent are initially unaware of the payoffs from the various projects. $\mathrm{P}$ acquires perfect information regarding the payoffs of all projects with exogenous probability $E$ but remains ignorant with probability $1-E$. A chooses effort $e$ devoted to acquiring information about the projects' payoffs and becomes perfectly informed with probability $e$ but learns nothing with probability $1-e$. We assume that training reduces the agent's marginal effort cost as captured in the effort cost function $g(e, I)$ with $\partial g / \partial e>0, \partial^{2} g / \partial e^{2}>0, \partial g / \partial I<0$, and $\partial^{2} g / \partial e \partial I<0 .{ }^{8}$ Since our formulation primarily intends to motivate the empirical analysis rather than suggest a general and thorough extension of AT's model, we ease analytical exposition by assuming the specific functional forms $c(I)=\theta I^{2} / 2$ and $g(e, I)=\rho e^{2} / 2 I$ (with $\theta>0$ and $\rho>0)$ throughout this section. This illustrative example sheds light on the main tradeoffs associated with delegation and allows reaching a closed-form solution.

The principal pays a wage $w \geq 0$ to the agent, who faces a fixed outside option represented by his reservation utility $\bar{u}$. (Appendix A shows how the model can be extended to incorporate incentive pay). We follow AT by considering

7. We also assume that for each party, there exists at least one project generating a loss of such magnitude that both $\mathrm{P}$ and $\mathrm{A}$ prefer inaction to implementing a random project in the absence of information about payoffs.

8. The assumption that the cross derivative of $g(\cdot)$ has a negative sign - that is, that A's marginal cost of becoming informed decreases with training - is a critical driving force of our results, since it implies that training is complementary to effort and therefore generates the rationale for positive human capital investment on the part of the employer. In essence, our formulation assumes that training increases the worker's productive efficiency in acquiring information about projects' payoffs. While acknowledging the possibility of alternative specifications, we consider such a conceptualization of training as a productivity-enhancing (or, equivalently, cost-reducing) investment to be reasonable. 
FIGURE 1

Time Sequence of Actions

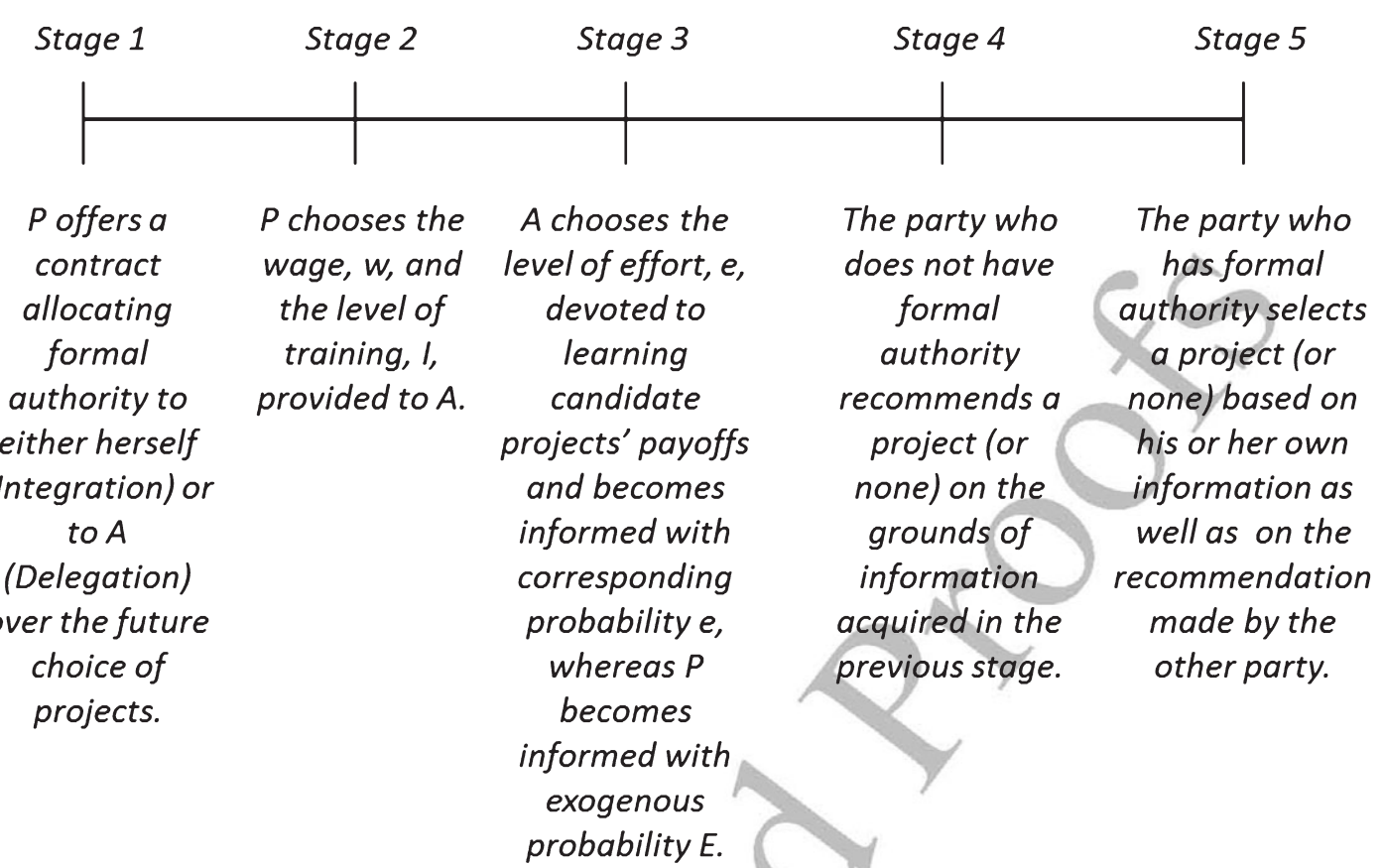

integration $(n)$ and delegation $(d)$. Under integration, $\mathrm{P}$ can overrule A's recommendation and, if informed, adopt her preferred project. Under delegation, $\mathrm{P}$ cannot overrule A's recommendation and optimally accepts it since $\alpha>0$. Of course, an uninformed agent will accept P's proposal (if any) given that $\beta>0$. Since the projects cannot be contracted upon ex ante, the model follows Grossman and Hart's (1986) incomplete contracting approach. Specifically, the initial contract allocates formal authority to either P or A and the overall sequence of actions is described in Figure 1.

Under integration, the payoffs of $\mathrm{P}$ and $\mathrm{A}, u_{p}^{n}$ and $u_{A}^{n}$ respectively, are given by:
(1) $u_{p}^{n}=E \cdot B+(1-E) e \cdot a B-c(I)-w$
(2) $u_{A}^{n}=E \cdot \beta b+(1-E) e \cdot b+w-g(e, I)$.

The payoffs associated with delegation are:

$$
u_{P}^{d}=e \cdot a B+(1-e) E \cdot B-c(I)-w
$$

(4) $u_{A}^{d}=e \cdot b+(1-e) E \cdot \beta b+w-g(e, I)$.

\section{B. Equilibrium}

The model is solved recursively under each authority structure (integration and delegation). In both cases, we first characterize A's optimal effort given the wage and training level. Then, we move back to identify the profit-maximizing training intensity and wage anticipating the worker's optimal effort and taking into account the latter's participation constraint. Finally, we establish the conditions under which $\mathrm{P}$ optimally selects to delegate formal authority to A.

CASE 1. Integration

Under integration, the agent chooses $e \in[0,1]$ so as to maximize $u_{A}^{n}$ and the associated firstorder condition is:

$$
\partial u_{A}^{n} / \partial e=(1-E) b-(\partial g / \partial e)=0 .
$$

Given our assumed functional forms, this condition implies the solution:

$$
e^{*}(I)=\min \{(1-E) b I / \rho, 1\} .
$$

The agent contributes more effort the higher is his private benefit $\left(\partial e^{*} / \partial b>0\right)$ and the lower 
1 is the probability that $\mathrm{P}$ becomes informed

$\left(\partial e^{*} / \partial E<0\right)$. Importantly, an increase in training induces $\mathrm{A}$ to work harder $\left(\partial e^{*} / \partial I>0\right)$ - by reducing his marginal cost of effort-that is, training is complementary to effort in this setting.

The principal anticipates $e^{*}(I)$ and chooses the level of training, $I^{n}$, and the wage, $w^{n}$, that maximize her payoff subject to A's participation constraint:

$$
\begin{gathered}
\max _{\{I, w\}} u_{p}^{n}=E \cdot B+(1-E) e^{*}(I) \cdot a B-c(I)-w \\
\text { s.t. } u_{A}^{n}=E \cdot \beta b+(1-E) e^{*}(I) \cdot b \\
+w-g\left(e^{*}(I), I\right) \geq \bar{u} \quad(P C) .
\end{gathered}
$$

Letting $\mu_{1}$ denote the multiplier of PC in the associated Lagrangian $\left(L_{1}\right)$ and assuming an interior solution $\left(w>0\right.$ and $\left.0<e^{*}<1\right)$, the first-order conditions with respect to $I$ and $w$ are:

$$
\begin{gathered}
\partial L_{1} / \partial I=(1-E) \cdot\left(\partial e^{*} / \partial I\right) \cdot a B-c^{\prime}(I) \\
+\mu_{1} \cdot\left(\partial u_{A}^{n}\left(e^{*}(I), I, w\right) / \partial I\right)=0 \\
\partial L_{1} / \partial w=-1+\mu_{1}=0 .
\end{gathered}
$$

Since $\mu_{1}=1>0$, the participation constraint will be binding at the optimal solution implying that $\mathrm{P}$ can use the wage to extract any variation in the surplus due to training. In Equation (7), the first term is P's marginal benefit associated with the positive impact of training on A's effort incentives while the second term is simply the marginal cost of training. Since $\partial u_{A}^{n} / \partial I=$ $(1-E)^{2} b^{2} / 2 \rho>0$, training raises A's utility and the third term in Equation (7) shows that $P$ has stronger training incentives when taking A's participation considerations into account. The solution of the above problem yields $I^{n}$ and $w^{n}$ which can then be substituted into $e^{*}(I)$ to derive the level of effort, $e^{n}$, as summarized in Equation (9):

(9) $\left(I^{n}, w^{n}, e^{n}\right)=\left((1-E)^{2} b(2 a B+b) / 2 \theta \rho\right.$,

$$
\left.\bar{u}-E \beta b-\left(b^{2}(1-E)^{2} I^{n}\right) / 2 \rho,\left((1-E) b I^{n}\right) / \rho\right) .
$$

The above expression evidently shows that training and wages are treated as substitutes by $\mathrm{P}$, since the provision of more training enables the principal to lower the wage while keeping A's participation constraint satisfied. ${ }^{9}$

9. The outcome in Equation (9) holds for $\theta>\theta^{n} \equiv b^{2}(1-E)^{3}(2 a B+b) / 2 \rho^{2} \quad$ (so that $\left.e^{n}<1\right)$ and sufficiently high values of $\bar{u}$ to ensure that $w^{n}>0$.
CASE 2. Delegation

When formal authority is delegated to A, the latter chooses $e \in[0,1]$ so as to maximize $u_{A}^{d}$ and the first-order condition is written as:

$$
\partial u_{A}^{d} / \partial e=(1-\beta E) b-(\partial g / \partial e)=0 .
$$

The solution yields the optimal effort function:

$$
\widehat{e}(I)=\min \{((1-\beta E) b I / \rho), 1\}
$$

where $\partial \hat{e} / \partial b>0, \partial \widehat{e} / \partial E<0$ (as before) and $\partial \widehat{e} / \partial \beta<0$ (since a higher $\beta$ increases A's payoff from implementing P's preferred project and so dampens A's incentive to become informed himself). The impact of training on effort is again positive but stronger than under integration $\left(\partial \hat{e} / \partial I>\partial e^{*} / \partial I\right)$. Comparing the optimal effort choices also reveals that $\hat{e}(I)>e^{*}(I)$. Given the training level, A faces the same marginal effort cost under either authority structure but reaps a higher marginal benefit under delegation (since $(1-\beta E) b>(1-E) b$ ) and thus has stronger incentives to become informed in this case.

Anticipating the new optimal choice $\hat{e}(I), \mathrm{P}$ now selects the training intensity, $I^{d}$, and the wage, $w^{d}$, which solve the following problem:

$$
\begin{gathered}
\max _{\{I, w\}} u_{p}^{d}=\hat{e}(I) \cdot a B+(1-\widehat{e}(I)) \cdot E B-c(I)-w \\
\text { s.t. } u_{A}^{d}=\widehat{e}(I) \cdot b+(1-\widehat{e}(I)) \cdot E \beta b \\
+w-g(\widehat{e}(I), I) \geq \bar{u} \quad\left(P C^{\prime}\right) .
\end{gathered}
$$

Denoting by $\mu_{2}$ the multiplier of PC in the associated Lagrangian $\left(L_{2}\right)$ and assuming again an interior solution, the first-order conditions with respect to $I$ and $w$ become:

$$
\begin{gathered}
\partial L_{2} / \partial I=(\partial \widehat{e} / \partial I) \cdot a B-(\partial \widehat{e} / \partial I) \cdot E B-c^{\prime}(I) \\
+\mu_{2} \cdot\left(\partial u_{A}^{d}(\widehat{e}(I), I, w) / \partial I\right)=0 \\
(13) \quad \partial L_{2} / \partial w=-1+\mu_{2}=0 .
\end{gathered}
$$

As before, $\mu_{2}=1>0$ and the participation constraint binds at the optimal solution. In Equation (12), the term $(\partial \widehat{e} / \partial I) \cdot a B$ represents P's marginal benefit from training due to fostering A's effort incentives. Yet, the term $(\partial \hat{e} / \partial I) \cdot E B$ represents a marginal cost associated with the reduced likelihood that $\mathrm{P}$ receives $B$ from her own preferred project and 
$c^{\prime}(I)$ is the marginal cost of training. Since $\partial u_{A}^{d} / \partial I=b^{2}(1-\beta E)^{2} / 2 \rho>\partial u_{A}^{n} / \partial I, \quad$ training increases A's utility relatively more under delegation and $\mathrm{P}$ takes this stronger effect into account when choosing the level of human capital investment. Solving for $I^{d}$ and $w^{d}$ and substituting back into $\widehat{e}(I)$ to derive the effort level, $e^{d}$, we finally obtain ${ }^{10}$ :

$$
\left(I^{d}, w^{d}, e^{d}\right)=\left\{\begin{array}{l}
(0, \bar{u}-E \beta b, 0), \text { if } a \leq a_{0} \equiv E-b(1-\beta E) / 2 B \\
\left(\frac{b(1-\beta E)[2(a-E) B+b(1-\beta E)]}{2 \theta \rho}, \bar{u}-E \beta b-\frac{b^{2}(1-\beta E)^{2} I^{d}}{2 \rho}, \frac{b(1-\beta E) I^{d}}{\rho}\right), \text { if } a \geq a_{0}
\end{array}\right.
$$

\section{The Impact of Delegation on Training Intensity}

The outcomes derived in Equations (9) and (14) can be compared to state the following Proposition.

PROPOSITION 1. When formal authority is delegated, the equilibrium training and effort intensity as well as the wage level can be either higher or lower than under integration. In particular:

$(\hat{a}, 1)$

i. $\mathrm{I}^{\mathrm{d}}<\mathrm{I}^{\mathrm{n}}$ for $a \in(0, \hat{a})$ and $\mathrm{I}^{\mathrm{d}}>\mathrm{I}^{\mathrm{n}}$ for $a \in$ $(\tilde{a}, 1]$

ii. $\mathrm{e}^{\mathrm{d}}<\mathrm{e}^{\mathrm{n}}$ for $a \in(0, \tilde{a})$ and $\mathrm{e}^{\mathrm{d}}>\mathrm{e}^{\mathrm{n}}$ for $a \in$

iii. $\mathrm{w}^{\mathrm{d}}>\mathrm{w}^{\mathrm{n}}$ for $a \in(0, \bar{a})$ and $\mathrm{w}^{\mathrm{d}}<\mathrm{w}^{\mathrm{n}}$ for $a \in(\bar{a}, 1]$

where $\quad 0<\bar{a} \equiv \frac{2 B E(1-\beta E)^{3}-b\left[(1-\beta E)^{4}-(1-E)^{4}\right]}{2 B\left[(1-\beta E)^{3}-(1-E)^{4}\right]}<$ $\tilde{a} \equiv \frac{2 B E(1-\beta E)^{2}-b\left[(1-\beta E)^{3}-(1-E)^{3}\right]}{2 B\left[(1-\beta E)^{2}-(1-E)^{3}\right]}<$ $\widehat{a} \equiv \frac{2 B E(1-\beta E)-b\left[(1-\beta E)^{2}-(1-E)^{2}\right]}{2 B\left[(1-\beta E)-(1-E)^{2}\right]}<1$.

The intuition underpinning Proposition 1 can be understood by also investigating the conditions under which the principal optimally chooses to delegate-authority. For this purpose, we write P's payoffs under integration and delegation as:

$$
\begin{aligned}
& u_{p}^{n}=E \cdot B+(1-E) e^{n} \cdot a B-c\left(I^{n}\right)-w^{n} \\
& =E(B+\beta b)-\bar{u}+\theta\left(I^{n}\right)^{2} / 2
\end{aligned}
$$

10. The results in Equation (14) hold for $\theta>\theta^{d} \equiv b^{2}(1-\beta E)^{2}\left[2(a-E) B+b(1-\beta E) / 2 \rho^{2} \quad\right.$ (so that $\left.e^{d}<1\right), B>b(1-\beta E) / 2 E$ (implying $\alpha_{0}>0$ ) and high enough values of $\bar{u}$ guaranteeing $w^{d}>0$.
(16)

$$
\begin{aligned}
u_{p}^{d} & =e^{d} \cdot a B+\left(1-e^{d}\right) \cdot E B-c\left(I^{d}\right)-w^{d} \\
& =E(B+\beta b)-\bar{u}+\theta\left(I^{d}\right)^{2} / 2 .
\end{aligned}
$$

This reformulation, combined with part (i) of Proposition 1, immediately leads to the following result.
PROPOSITION 2. The principal prefers delegation if and only if the congruence parameter $\alpha$ is sufficiently high: $u_{p}^{d}<u_{p}^{n}$ for $a \in(0, \hat{a})$ and $u_{p}^{d}>u_{p}^{n}$ for $a \in(\widehat{a}, 1]$.

The central tradeoff associated with delegation here is the same as in AT's seminal model. Delegation induces A to work harder (given the training intensity) and thus tends to increase P's expected payoff (this is the incentive effect). At the same time, however, it may lead to the selection of projects which are less preferred by $\mathrm{P}$ (this is the loss-of-control effect). When the congruence parameter $\alpha$ is sufficiently high - that is, when A's preferred project yields a large enough benefit to $\mathrm{P}$ - the incentive effect dominates and $P$ chooses delegation. In our formulation, training is complementary to effort and proportionally amplifies this tradeoff. Therefore, the conditions under which delegation and training are positively related are identical to those determining whether $\mathrm{P}$ delegates authority or not (as confirmed by inspection of Proposition 2 and part (i) of Proposition 1). ${ }^{11}$

The top panel of Figure 2 graphically depicts the relationship between $I^{d}$ and $I^{n}$, whereas the middle panel shows the relationship between $e^{d}$ and $e^{n}$. Since the positive impact of $\alpha$ on training and effort is relatively stronger under delegation, the curves $I^{d}(a)$ and $e^{d}(a)$ are steeper than $I^{n}(a)$ and $e^{n}(a)$ and therefore the training and effort intensities under delegation exceed those under integration beyond the threshold values $\hat{a}$ and $\tilde{a}$, respectively. The bottom panel of Figure 2 plots the wage levels under each authority structure. Increasing $\alpha$ induces more training in both cases, thereby enhancing A's utility and lowering

11. We are grateful to an anonymous referee for illuminating this identity. 


\section{FIGURE 2}

The Top Panel Shows Training Intensity, the Middle Panel Shows Worker's Effort and the Bottom Panel Shows the Wage Level with and Without Delegation

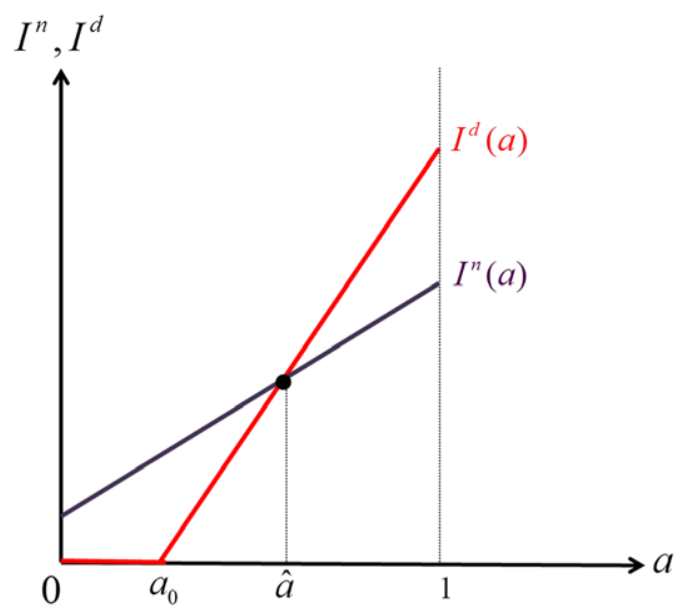

$e^{n}, e^{d}$

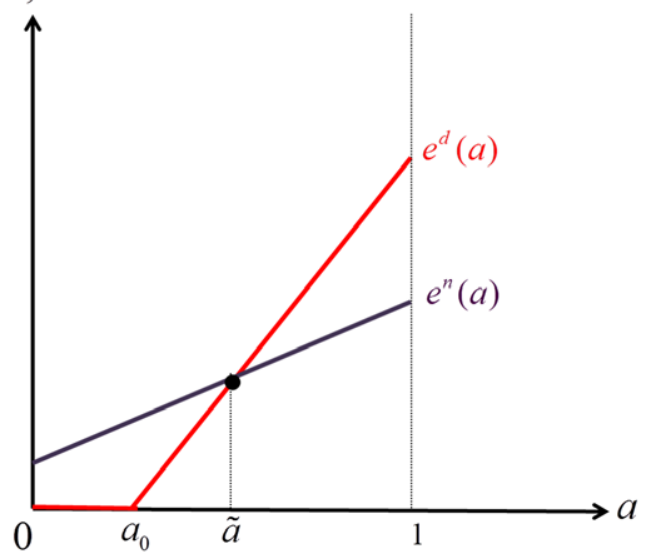

$w^{n}, w^{d}$

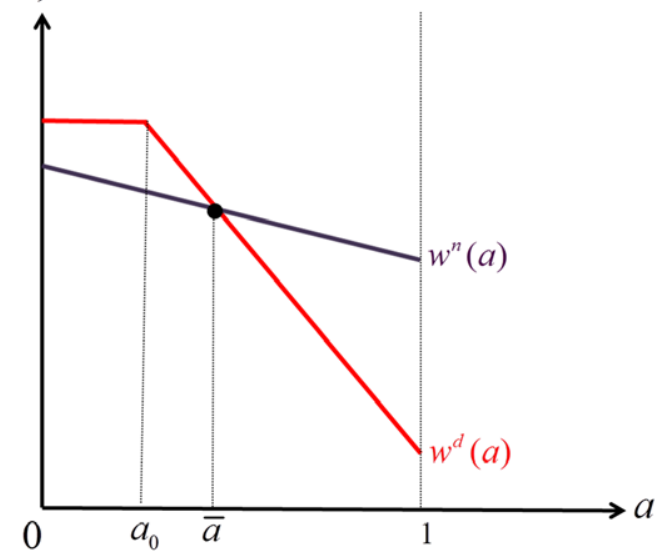

the wage necessary to satisfy A's participation constraint. The curve $w^{d}(a)$, however, falls faster than $w^{n}(a)$ implying that $\mathrm{P}$ pays a relatively lower wage under delegation when $\alpha$ exceeds the cutoff level $\bar{a}$. More generally, our analysis makes clear that the impact of delegation on training is ambiguous and depends on the critical congruence parameter, thus fueling our empirical estimates to identify the dominant pattern. ${ }^{12}$

\section{DATA AND EMPIRICAL METHODOLOGY}

In what follows we detail our data and present our methodology for examining the influence of delegation on training. We stress the potential difficulties introduced by using linked data and the need to hold constant unmeasured establishment specific influences. We also emphasize the need to account for potential endogeneity. In line with our theoretical model, the objective is to get as close as possible to a test of the exogenous influence of delegation.

\section{A. Workplace Employment Relations Surveys} Data

We draw data from the 2004 and 2011 Workplace Employment Relations Surveys (WERS). The surveys randomly select UK workplaces with five or more employees from the Interdepartmental Business Register, considered the highest quality available sampling frame. A smaller panel exists of establishments responding in both surveys. The sampling stratifies by workplace size and industry with larger workplaces and some industries overrepresented (Chaplin et al. 2005). As a consequence, all the estimates we present use workplace weights (separate weights exist for the cross sections and panel) to ensure that the results are nationally representative of British workplaces. ${ }^{13}$ The sampling weights adjust for a number of factors influencing the probability of selection, and the stratification by workplace size and industry (see Kersley et al. 2006). We exclude establishments not in the trading sector (government and nonprofits) and those with missing data on the critical dependent variable

12. Appendix A extends our model by introducing incentive pay as an additional instrument available to the firm, thus enabling the latter to use both training and the appropriate design of wage incentives to elicit more productive effort from the worker.

13. We have experimented with employment weights and the results remain robust. 
14. The response rates of the employee questionnaire

measuring training and on the main independent variable capturing delegation.

Nearly all data, including the training measure, come from the "Management Questionnaire," a face-to-face interview with the most senior manager with responsibility for personnel matters. We use, however, the linked "Employee Questionnaire" for our preferred delegation measure as described below. The response rates for 2004 and 2011 were $64 \%$ and $46 \%$ yielding 2,295 and 2,680 establishments, respectively. Response rates are decreasing through time reflecting business surveys trends (Van Wanrooy et al. 2013). ${ }^{14}$ After our restrictions, the sample sizes are 994 in 2004, 1,012 in 2011, and 474 in the panel.

Managers indicate the proportion of employees formally trained. The specific question asks: (COFFJOB) "What proportion of experienced employees in the largest non-managerial occupational group have been given time off from their normal daily work duties to undertake training over the past 12 months." The responses include None (0\%), Just a few $(1 \%-19 \%)$, Some $(20 \%-39 \%)$, Around half $(40 \%-59 \%)$, Most (60\%-79\%), Almost all (80\%-99\%), and All $(100 \%)$. Table 1 provides the distribution of responses showing that around $24 \%$ of the establishments trained none of their employees in 2004 . This fell to $19 \%$ in 2011 and was $17 \%$ in the panel. About $30 \%$ of the establishments trained all employees in 2004. This increased to $35 \%$ in 2011 and was about $30 \%$ in the panel for 2004 and 2011 were $60 \%$ and $54 \%$ yielding 22,451 and 21,981 employees, respectively.
TABLE 1 using ordered probits for simple cross-sectional analysis but we must use a linear count variable (ordering the categories from 1 to 7 ) for the fixed effect and IV estimates.

This training measure remains broad and likely includes some training that is not related to information acquisition. While recognizing this, we emphasize that the notion of "investment" from the theoretical model should not be taken too narrowly. Some of the information acquisition resulting from training could include better ways to organize the steps in production or how to optimize break times. While not explicitly investments in "plant and equipment" these investments seem both a good fit with the theory and likely to result from a large variety of types of worker training. Also note that we will make use of an alternative training measure and experiment with creating a more pointed version of our current measure without substantial changes in the results. ${ }^{16}$

Our preferred delegation measure (we will examine alternatives) comes from the employee questionnaire. At each establishment up to 25 employees are randomly selected (every

15. There were 989 workplaces in WERS 2004 that also participated in WERS 2011. The response rate of the panel questionnaire was $52 \%$.

16. The experiment noted that firms which provide information to workers about potential investments engage in a full category greater training on average. We then restricted our delegation measure to apply only to those firms that provide investment information (we assumed there was no meaningful delegation without such information). The estimations with this narrower measure remain very similar and are available upon request. 
TABLE 2

employee is questioned at establishments with less than 25) and asked: "In general, how much influence do you have about the range of tasks you do in your job?" Responses are recorded on a 4-point scale: 1 "None," 2 "A little," 3 "Some," and 4 "A lot." Following De Varo and Kurtulus (2010), we identify delegation as present when the modal response across an establishment's workers is "A lot" and absent when the modal response is "Some," "A little," and "None." Thus, we take the most frequently occurring worker response to reflect the degree of delegation in that workplace. ${ }^{17}$

While this measure is subjective, it has been shown to provide a reasonable proxy for delegation to workers (seeDe Varo and Kurtulus 2010De Varo and Prasad 2015). Yet, it differs in critical ways from other measures of delegation. First, it need not reflect the decision of actual firm owners. Thus, the delegation we observe may be from managers to workers, a point we return to in our robustness exercises. Second, it differs from measures on whether decisions are made centrally or at the plant level (Meagher and Wait 2014). Despite these differences, it remains appropriate for thinking about the provision of training.

Table 2 shows that the delegation responses display significant variation across workplaces and oyer time. About one out of three workplaces delegated in 2004 while $49 \%$

17. We experimented with the mean and the median of this measure and results remain robust. More fundamentally, we also imagined retaining the mode but changing the cutoff so that either reports of "A lot" or "Some" were identified as delegation. We also imagined simply entering three dummies for whether the mode was "A little," "Some," or "A lot." Neither of these reasonable alternatives to structuring the critical independent variable change the fundamental results we report and they are each available upon request. delegated in 2011 and almost 40\% delegated in the panel.

In supporting information, we show that delegation is most widespread in manufacturing, utilities and construction where more than three-quarters of the workplaces have employees reporting "a lot" of delegation. The share is intermediate in finance, health and education (around half), and relatively small in transport and communication, wholesale and retail trade. There is no significant correlation with the extent of training by industry. Training is most widespread in utilities, transport and communication, education and health; intermediate in transport, construction and manufacturing and low in wholesale and retail trade. The supporting information also breaks the four incentive schemes by industry, as well as offering a breakdown of the extent of training, delegation, and incentive schemes by firm size.

\section{B. Empirical Methodology}

We seek to determine whether or not delegating to workers increases a firm's incentive to provide training. We acknowledge that not only training but also many of the other variables in the WERS are likely to be endogenous. As made clear, our theoretical model takes delegation as given and traces out the consequences. Thus, our empirical strategy initially presents a series of estimations that may be described as descriptive although we feel we do a good job of controlling for most of the relevant confounders. Then, we move closer to testing for an exogenous influence of delegation. This is done through IV estimates and a series of robustness tests on those IV estimates.

We initially estimate cross-sectional ordered probits in which the categorical training measure 
depends on delegation. ${ }^{18}$ Since our delegation measure is built up from the employee questionnaire, we face a typical generated regressor problem (see, e.g., Murphy and Topel 1985; Pagan 1984). In response, we bootstrap the data using 1,000 replications with replacement and throughout we report only bootstrapped standard errors.

We first present the ordered probit of training against the delegation measure and a limited set of controls. We recognize that fixed costs in establishing training imply that larger organizations provide training more efficiently (Barron, Berger, and Black 1997; Black, Noel, and Wang 1999; Booth 1991; Holtmann and Idson 1991). Moreover, such training programs may take time to develop and may reflect the permanence and scope of the establishment. Thus, we control for the (log) number of employees, if the workplace has been operating for more than 5 years, whether the workplace is part of a larger organization (i.e., multiworkplace) or is a single independent workplace, and if the workplace is UK owned/controlled.

In the second estimate, we capture workforce characteristics known to influence training provision. These include the percentage of employees using computers, of female employees (Green and Zanchi 1997), of part-time employees, and of trade union members (Boheim and Booth 2004; Dustmann and Schönberg 2007; Green, Machin, and Wilkinson 1999). Recognizing the connection between the incentive to train and the extent of labor mobility (Arulampalam and Booth 1998), we also control for the percentages of employees on fixed-term contract, of temporary agency employees, and of employees who separate and quit in the previous year. We also add controls for the educational attainment of the workforce and the share of the workforce in each of eight occupational groups and we include seven dummies identifying the largest nonmanagerial occupational group.

In a third estimate, we capture variation of training across industries and regions by adding ten industry dummies and nine region dummies. The fourth estimate adds variables for performance pay and market structure (Bilanakos et al. 2017) and represents our most complete specification. There are four indicators of performance pay (whether or not the nonmanagerial workers receive payment by result, merit pay, profitrelated pay, or share ownership). The market

18. Appendix Table A1 reports the descriptive statistics of all the variables used in the analysis. structure variables are whether there are no, few, or many competitors and whether the product market is growing, mature, turbulent, or declining. ${ }^{19}$

We recognize the possibility of unmeasured establishment characteristics that influence both the extent of training and delegation. Thus, superior management may both train more and delegate more. Failing to control for management quality could bias the cross-section results. We respond by estimating workplace fixed-effect models. The resulting within-establishment variation eliminates the influence of unmeasured time-invariant determinants of training allowing a potentially superior estimate. As fixed-effect ordered probits suffer from the incidental parameter problem associated with many nonlinear estimates (see Greene 2001), we supplement our analysis with OLS and Poisson fixed-effect estimates that do not suffer from this problem (Hilbe and Green 2008). The results across the estimates remain very similar and continue to show an important role for delegation.

We further recognize that fixed-effect estimates need not eliminate the possibility of endogeneity. Thus, superior management may be new to the establishment generating a spurious correlation even in the fixed-effect estimates. Moreover, training may determine delegation. Thus, it could be that only once an establishment has trained its workforce will it have trust in its ability to meaningfully delegate authority. To account for such fears of endogeneity and reverse causation, we adopt an IV strategy based on industrial aggregation (Fisman and Svensson 2007; Lai and $\mathrm{Ng}$ 2014) that we describe in detail when presenting the results. We implement this IV strategy both for the cross-section and workplace fixedeffect estimates in the panel.

Finally, we undertake a series of robustness exercises designed to probe the stability and reliability of the relationship. These involve alternative variables for the key concepts, altering specifications, and estimating within critical subsamples. The results appear remarkably robust and at least point strongly toward an exogenous influence of delegation.

19. While Bilanakos et al. (2017) present UK evidence that dominant firms do more training, Meagher and Wait (2014) present Australian evidence that delegation itself is associated with more competitive product markets. Thus, while initially controlling for these critical variables, we ultimately tackle the implied concern with the endogeneity of delegation. 


\section{EMPIRICAL RESULTS}

\section{A. Ordered Probit Analysis}

The first column of Table 3 presents the estimate for 2004. The coefficient on employee delegation is positive and statistically significant fitting the contention that delegation increases the extent of training. It also shows the traditional result that larger establishments provide more training. Column 2 adds workforce characteristics indicating that establishments provide more training when their employees work with computers, are female, unionized and employed full time. The magnitude of the estimated coefficient on delegation increases and becomes significant at the $1 \%$ level. Column 3 shows that the magnitude of the coefficient on delegation increases again after allowing the extent of training to differ across industries, occupations, and regions. Finally, column 4 shows that dominant firms train more (see Bilanakos et al. 2017) as do firms that provide profit-related pay. Worker mobility, however, is associated with less training. The coefficient on delegation retains size and significance. There exists no indication that more complete specifications reduce the role of delegation.

Column 5 provides estimates from an OLS model that treats training as a cardinal count value from 1 to 7 . The coefficient indicates that delegation is associated with an increase of 0.422 of a training category. While we will shortly present the full marginal effects from the ordered probit, we report the OLS in order to make comparisons with the other linear estimates that we report later.

In Table 4, we reproduce the series of estimates for 2011. The pattern of the controls and the size and significance of the delegation coefficient remain remarkably similar. Again, in column 5, we present an OLS estimate indicating that delegation is associated with an increase of 0.488 of a training category.

In Table 5, we report the full marginal effects of delegation from the final ordered probit estimates. Column 1 indicates that in 2004 delegation is associated with a decrease of 0.039 in the probability of offering no training, and an increase of 0.077 in the probability of training all workers. Column 2 indicates that in 2011, delegation is associated with a decrease of 0.030 in the probability of offering no training and an increase of 0.090 in the probability of offering training to all workers. An increase of 0.090 represents a $26 \%$ increase on the mean probability of 0.349 . The marginal effects are broadly similar across the two surveys and suggest that the magnitudes of the statistical relationship are economically consequential. Workplaces that delegate offer more training, a relationship that we now probe more deeply.

\section{B. Panel Estimates}

Despite the fact that our measure of delegation comes from the employee questionnaire, an innovation in the WERS allows us to retain our delegation measure in the workplace panel. Prior to the most recent two waves (2011 and 2004), the WERS panel was a separate set of establishments that could not be taken back to the linked employee data available in the cross sections. For the first time, the panel is now part of the cross sections and so linked to the employee data for 2011 and 2004. Incorporating workplace fixed effects removes time-invariant unobserved heterogeneity such as some workplaces having routinely superior management. Thus, it presents a relevant robustness exercise.

Column 1 of Table 6 presents a pooled ordered probit estimate without fixed effects on the panel of workplaces. The delegation coefficient is very close in size to those from the cross sections suggesting that the panel is not a highly selected sample. Column 2 presents the OLS estimate which treats the ordered categories of training as cardinal and indicates that delegation is associated with 0.379 of a category more training. ${ }^{20}$

Column 3 shows that the OLS fixed-effect coefficient remains highly significant and modestly larger in magnitude than in the pooled OLS. Thus, there appears no evidence that unmeasured time-invariant characteristics generate a downward bias. The column 3 estimates indicate that firms which delegate increase their training by 0.389 of a category.

As a robustness check, we estimate alternative functional forms for the fixed-effects estimate. The dependent variable may be better considered a count variable allowing estimation of the fixed-effect Poisson regression. This is one of the few nonlinear fixed-effect estimators without incidental parameters concerns (Hilbe and Green 2008). The results are presented in column 4 and show that the estimated coefficient retains an economically significant

20. All fixed-effects specifications in our analysis include industry controls. Even though reported industry switches from 2004 to 2011 are rare, they do happen, so the models are estimated with the industry controls. If the industry controls are dropped from our analysis, the results remain essentially unchanged. 
TABLE 3

Dependent Variable: Categorical Measure of Share Trained (WERS 2004)

4

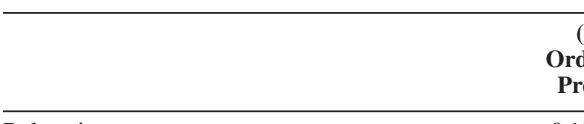

Delegation

Log number of employees

Workplace operates more than 5 years

Part of a larger organization

Single independent workplace

UK owned

$\%$ of employees using computers

$\%$ of female employees

$\%$ of part-time employees

$\%$ union membership

$\%$ of employees with a fixed-term contract

$\%$ of employees with a temporary contract

$\%$ of employees who quit last year

$\%$ of employees dismissed/redundant last year

Payment by result

Merit pay

Profit-related pay

Employee share schemes

Few competitors

Many competitors

Market growing

Market mature

Market declining

Cutoff 1

Cutoff 2

Cutoff 3

Cutoff 4

Cutoff 5

Cutoff 6

Constant

\section{Observations}

$R^{2}$

Educational composition

Occupational composition

Largest Occupational groups

Industry dummies

Region dummies

Missing dummies

\section{rdered}

Probit

$0.184 * *$

(0.073)

$0.079 * * *$

(0.021)

$-0.119$

(0.130)

$0.328 *$

(0.180)

0.041

(0.191)

$-0.109$

(0.088)

(2)
Ordered

(3)

Ordered Ordered

Probit

Probit

$0.213 * * *$

$(0.079)$
$0.071 * *$

(0.029)

$-0.182$

(0.144)

0.311

$(0.190)$

0.148

(0.202)

$-0.180^{*}$

(0.103)

$0.389 * * *$
$(0.140)$

$0.747 * * *$

(0.206)

$-0.754 * * *$

(0.210)

0.432
$(0.158)$

$(0.158)$
$0.341 *$

(0.205)

$-0.155$

(0.461)

$-0.153$

(0.252)

$-0.700$

$(0.430)$

$0.242 * * *$

(0.081)

$0.098 * * *$

(0.030)

$-0.188$

(0.147)

0.221

(0.208)

0.100

(0.221)

$-0.232 * *$
$(0.108)$

$(0.108)$
$0.420 * * *$

(0.141)

$0.824 * * *$

(0.239)

$-0.818^{* * *} *$
$(0.223)$

0.389 **

(0.171)

0.401 *

(0.221)

-0.212
$(0.491)$

$(0.491)$
-0.207

$(0.255)$

$-0.570$

(0.457)

(15)

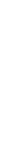

0.236 ****

$0.083^{*} * *$

$(0.031)$

$-0.160$

(0.150)

(0.219)

(0.233)

$-0.236 * *$

(0.108)

$0.360^{*}$
$(0.146)$

$(0.146)$
$0.808 * * *$

$(0.243)$

$-0.847 * * *$

(0.230)

$0.444 * *$

$(0.179)$
$0.379 *$

(0.225)

$-0.342$

(0.503)

$-0.264$

(0.262)

$-0.818 *$

(0.458)

0.012

(0.095)

0.010

(0.113)

0.218 **

(0.088)

0.119

Notes: Bootstrap standard Estimates use workplace weights. $* * * p<.01, * * p<.05, * p<.1$.

OLS 5

$0.422 * * *$

$(0.142)$
$0.153 * * *$

(0.052)

$-0.208$

(0.259)

0.398

(0.393)

0.252

(0.410)

(0.106)

$-0.285^{*}$

(0.147)

$-0.342 * *$

(0.144)

$0.175^{*}$

(0.106)

0.031

(0.118)

$-0.238$

(0.160)

$-0.287$

(0.488)

0.399

(0.488)

0.812 *

(0.488)

$1.128 * *$

(0.489)

$1.354 * * *$

(0.488)

$1.712 * * *$

(0.490)

$(0.192) \quad 13$

$0.651 * * * \quad 14$

(0.242) 15

$1.439 * * *$

(0.406)

$-1.281 * * *$

(0.368)

$0.729 * *$

(0.306)

0.673 *

(0.395)

$-0.469$

(0.792)

$-0.345$

(0.438)

$-1.792 * *$

(0.806)

0.081

(0.166)

0.065

(0.205)

$0.400 * * *$

(0.153)

0.201

(0.188)

$-0.292 *$

(0.165)

$-0.357 * *$

(0.163)

0.339 *

(0.185)

0.058

(0.208)

$-0.350$

(0.274)

$1.064 *$

$1.287 * * *$

(0.432)

$1.642 * * *$
$(0.434)$

(0.490)

$994 \quad 994$

(0.841)

994

0.248

Yes

Yes

Yes

Yes 
TABLE 4

Dependent Variable: Categorical Measure of Share Trained (WERS 2011)

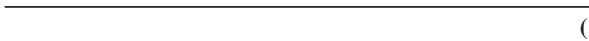

Deteging

Delegation

Log number of employees

Workplace operates more than 5 years

Part of a larger organization

Single independent workplace

UK owned

$\%$ of employees using computers

$\%$ of female employees

$\%$ of part-time employees

$\%$ union membership

$\%$ of employees with a fixed-term contract

$\%$ of employees with a temporary contract

$\%$ of employees who quit last year

$\%$ of employees dismissed/redundant last year

Payment by result

Merit pay

Profit-related pay

Employee share schemes

Few competitors

Many competitors

Market growing

Market mature

Market declining

Cutoff 1

Cutoff 2

Cutoff 3

Cutoff 4

\section{Cutoff 5}

Cutoff 6

Constant

(1)
rdered

Probit

(2)

Ordered

(3)

Ordered

$0.229 * * *$

$0.236^{* * * *}$
$(0.070)$

$0.070 * * *$

(0.021)

$-0.014$

(0.151)

0.258

(0.204)

$-0.085$

(0.217)

$-0.097$

(0.096)

$0.229 * * *$

$(0.073)$
$0.063 * *$

Probit

(0.032)

-0.045
$(0.157)$

0.205

(0.204)

$-0.077$

(0.220)

$-0.189 *$

$0.445^{* * *}$

(0.145)

$0.568 * * *$

(0.201)

-0.432 **

(0.182)

$0.783 * * *$

(0.183)

$0.741 * * *$

(0.208)

0.227

(0.413)

$-0.632 *$

(0.357)

$-0.526$

(0.340)

$0.245^{* * *} *$

(0.075)

$0.076 * *$

(0.034)

$-0.045$

(0.163)

0.221

(0.212)

$-0.063$

(0.228)

$-0.195 *$

(0.114)

(0.149)

0.443 **

(0.220)

$-0.524 * * *$

(0.194)

$0.848 * * *$

$(0.206)$
$0.737 * * *$

(0.211)

0.161

(0.452)

$-0.463$

$(0.369)$
-0.520

(0.374)

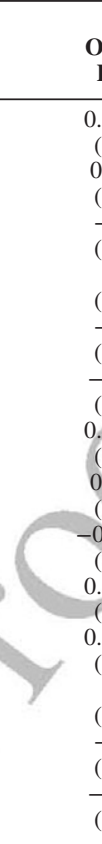

(4)
Ordered

Probit

(5)

$0.245 * * *$

$(0.077)$

$0.069 * *$

(0.035)

$-0.045$

0.207

(0.214)

$-0.056$

(0.232)

-0.210 *

(0.117)

0.430 ****

$(0.152)$
$0.453 * *$

(0.224)

$-0.532 * * *$

(0.194)

0.860 ***

(0.214)

$0.747 * * *$

(0.212)

0.122
$(0.466)$

$-0.473$

(0.375)

$-0.680 *$

(0.390)

0.021

(0.101)

0.099

(0.106)

0.175 **

(0.087)

0.072

(0.129)

$-0.428 * *$

(0.213)

-0.439 **

(0.214)

0.195 **

(0.098)

0.196*

(0.113)

$-0.148$

(0.129)

0.692

(0.567)

$1.312 * *$

(0.566)

$1.772 * * *$

(0.566)

2.032 ***

(0.565)

2.271 ***

(0.565)

$2.657 * * *$

$(0.475)$
$2.142 * * *$

(0.476)

(0.530)

$2.402 * * *$

(0.567)

$$
\text { (0.261) }
$$

(0.531)

\section{1,012}

1,012

Yes

Yes

Yes

Yes

Yes
Yes

$-0.941$

(0.617)

$-0.695 *$

(0.412)

0.124

(0.181)

0.169

(0.184)

$0.336^{* *}$

(0.151)

0.095

(0.233)

$-0.498 * *$

(0.250)

$-0.502 * *$

(0.247)

0.338 **

(0.166)

$0.337^{*}$

(0.195)

$-0.281$

(0.226) 
TABLE 5

Marginal Effects

\begin{tabular}{|c|c|c|c|c|}
\hline \multirow[b]{4}{*}{ Training } & \multirow{2}{*}{\multicolumn{2}{|c|}{$\begin{array}{c}\text { WERS } 2004 \\
\text { (1) }\end{array}$}} & \multirow{2}{*}{\multicolumn{2}{|c|}{$\begin{array}{c}\text { WERS } 2011 \\
\text { (2) }\end{array}$}} \\
\hline & & & & \\
\hline & \multicolumn{2}{|c|}{ Delegation } & \multicolumn{2}{|c|}{ Delegation } \\
\hline & $M E$ & $S E$ & $M E$ & $S E$ \\
\hline Cutoff 1: none & $-0.039 * * *$ & 0.012 & $-0.030 * * *$ & 0.010 \\
\hline Cutoff 2: just a few & $-0.037 * * *$ & 0.013 & $-0.034 * * *$ & 0.011 \\
\hline Cutoff 3: some & $-0.016^{* * *}$ & 0.006 & $-0.024 * * *$ & 0.008 \\
\hline Cutoff 4: around half & -0.003 & 0.002 & $-0.008 * * *$ & 0.003 \\
\hline Cutoff 5: most & $0.004 * *$ & 0.002 & $0.002 *$ & 0.001 \\
\hline Cutoff 6: almost all & $0.014 * * *$ & 0.005 & $0.008 * * *$ & 0.002 \\
\hline Cutoff 7: all & $0.077 * * *$ & 0.027 & $0.090 * * *$ & 0.028 \\
\hline
\end{tabular}

Notes: Entries are marginal effects obtained from a weighted ordered probit model based on the estimates reported in column 4 of Table 3 (WERS 2004) and in column 4 of Table 4 (WERS 2011), respectively. We only report the marginal effects of the variable of interest. Marginal effects for all the other covariates are available upon request. Robust standard errors are obtained using a bootstrap exercise with 1,000 replications with replacement and are clustered at workplace cells.

$* * * p<.01, * * p<.05, * p<.1$.

magnitude and statistical significance. We also estimate conditional fixed-effect logits (which eliminate the incidental parameter problem) by dividing the categories of training into high and low, as well as fixed-effect ordered probits (available as a canned routine in LIMDEP) that retain the incidental parameter problem. We present the results in the online Appendix Table S1, Supporting Information, to this paper and confirm the pattern of estimates shown in Table 6. The estimates are remarkably similar across establishments and within establishments, thus when an establishment moves to delegate it provides more training. ${ }^{21}$

\section{Endogeneity and IV Estimates}

While the fixed-effect estimates are reassuring, we recognize that the positive correlation between delegation and training could still

21. We also searched for a proxy to the theoretical product market uncertainty, $E$. The WERS question closest asks if the product market is "growing," "mature," "declining" or "turbulent." If we identify uncertain environments as "turbulent," then this variable and its interaction with delegation take insignificant coefficients. If we identify uncertain environments as both turbulent and declining markets, then the interaction takes a negative and significant coefficient that essentially eliminates the influence of delegation. These results are available upon request. Thus, if one thought high $E$ was associated with turbulent or declining product markets, the suggestion that delegation has no influence might be seen as broadly fitting with the theory. Yet, we emphasize that the available question is not a particularly good theoretical fit. Lo et al. (2016) proxy environmental uncertainty using two measures, rapid technological change, and industry demand uncertainty. They find that both measures of environmental uncertainty have a negative but not always statistically significant effect on price delegation. emerge endogenously. As an illustration, superior management could arrive between the two observations. Here, a critical determinant is not time invariant. More dramatically, the causation could be reversed. A more trained workforce reassures the firm that employees are sufficiently equipped to have more influence.

To examine these possibilities, we undertake an IV strategy based on industrial aggregation (examples include Fisman and Syensson 2007 and Lai and $\mathrm{Ng}$ 2014). The strategy posits that unmeasured characteristics of an industry help to define the extent of delegation by workplaces within that industry. In our case, these industry characteristics stand as exogenous influences that make it more or less likely that firms within the industry will delegate. They may reflect the nature of the product and the underlying technology. The empirical implementation generates an identifying variable that aggregates the delegation indicator. This aggregate varies by workplace within the industry by excluding the workplace for which it is computed. Thus, the identifying variable is the proportion of workplaces in industry cells reporting "A lot" of delegation after removing the given workplace from the industry cell.

Table 7 provides estimates from the panel and again contrasts an estimate that does not hold constant workplace fixed effects (columns 1 and 2) with one that does hold them constant (columns 3 and 4). Using two-stage least squares (2SLS), linear probability models are estimated in the first stages for the endogenous delegation indicators with the cardinal value of the training variable as the ultimate second stage-dependent variable. The second stage returns the estimated values from the first stage along with the joint variables to estimates on training. The first stage routinely shows a strong positive correlation between the industry average and the excluded establishment value. There is no evidence of a weak instrument and the other diagnostics are also supportive. The second-stage panel estimate of delegation is very close to the magnitudes for the two cross sections, again showing that the panel data is not a highly selected sample. ${ }^{22}$ Here, the standard errors are clustered at the workplace level.

Columns 3-4 combine the IV strategy with a workplace fixed-effect estimate. We alter the procedure slightly from the pooled estimates by

22. These IV estimates on the cross section are available as Table S2 in the online appendix. 
TABLE 6

Panel Data 2004-2011

\begin{tabular}{lcccc}
\hline & $\begin{array}{c}(\mathbf{1}) \\
\text { Ordered Probit } \\
\text { without FE }\end{array}$ & $\begin{array}{c}\text { (2) } \\
\text { OLS } \\
\text { without FE }\end{array}$ & $\begin{array}{c}\text { (3) } \\
\text { OLS } \\
\text { with FE }\end{array}$ & $\begin{array}{c}\text { (4) } \\
\text { Poisson } \\
\text { with FE }\end{array}$ \\
\hline Delegation & $0.214^{* *}(0.092)$ & $0.379^{* *}(0.164)$ & $0.389^{* *}(0.192)$ & $0.246^{* *}(0.121)$ \\
Log-likelihood & -658.424 & & & -170.542 \\
$R^{2}$ & & 0.341 & 0.895 & \\
Observations & 474 & 474 & 474 & 474 \\
Industry dummies & Yes & Yes & Yes & Yes \\
Region dummies & Yes & Yes & No & No \\
Workplace characteristics & Yes & Yes & Yes & Yes \\
Workforce characteristics & Yes & Yes & Yes & Yes \\
Occupational composition & Yes & Yes & Yes & Yes \\
Largest occupational group dummies & Yes & Yes & Yes & Yes \\
PRP dummies & Yes & Yes & Yes & Yes \\
Competition dummies & Yes & Yes & Yes & Yes \\
Market state dummies & Yes & Yes & Yes & Yes \\
Missing dummies & Yes & Yes & Yes & Yes \\
\hline
\end{tabular}

Notes: For information on the sample and on the main variables of interest, see Notes in Tables 1 and 2. The dependent variable is the proportion of experienced employees in the largest occupational group who have been given time off from their normal daily work to undertake training over the last 12 months. For reasons of brevity, we only present estimates of the main independent variable of interest. Other controls are those shown in column 4 of Table 3 , as well as a year dummy. The estimates for the rest of the covariates are available upon request. Bootstrap standard errors using 1,000 replications with replacement and clustered at workplace cells are reported in parentheses. Estimates are weighted using workplace weights.

$* * * p<.01, * * p<.05, * p<.1$.

now clustering errors at the industry level as each pair of workplace observations now contribute at most once to the workplace fixed-effect estimate. Column 3 presents the first stage results. Estimates suggest that establishments that are part of a larger organization, offer payment by result, and operate in growing markets are more likely to delegate. The latter two results are in line with Lo et al. (2016) who find that price delegation is higher when firms offer pay for performance and when there is less market uncertainty. Column 4 presents the second stage results. This second-stage IV estimate with workplace fixed effects is modestly larger. The results indicate an increase of 0.538 of a category. This is noticeably larger than the comparable fixed-effect estimate of 0.389 of a category without the IV (see column 3 of Table 6). As the bands of training are roughly 20 percentage points each, moving 0.538 of a band is roughly equivalent to training an additional $11 \%$ of the establishment's workforce. The diagnostics continue to be supportive. ${ }^{23}$

23. While not formal tests, two results support our strategy. First, if delegation is predicted using training in a workplace fixed-effect estimate, it is simply irrelevant hinting that reverse causation may not be an issue. Second, when the assumed exogenous industrial aggregation is added to a single stage workplace fixed-effect estimate of training, it emerges with a very small and insignificant coefficient, less than 0.01 ( $t$-stat of 0.60 ), even as the coefficient on delegation remains large and highly significant. This suggests we have introduced meaningful exogenous variation.
These estimates suggest that plausibly independent movements of delegation are associated with the extent of training. The fact that the IV estimate tends to be larger may reflect that instrumenting has reduced measurement error and the associated attenuation bias. Alternatively, it may reflect a truly larger local treatment effect. The critical point remains that there exists no evidence that failure to instrument generates an upward bias. When the IV is combined with the fixed-effect estimates, they add confidence to our results and seem sensible. Moreover, these estimates come closer to testing our theoretical notion that exogenous changes in delegation increase training.

Yet, we recognize that our IV does not guarantee unbiasedness when some other potentially endogenous variables remain uninstrumented. So we ran a variation that limited the included controls to only the region and industry dummies. These specifications look broadly similar with no indication of a weak instrument, and an IV indicating that delegation is associated with a significant increase of 0.388 of a training category (see online appendix Table S3).

We undertook a series of additional variations in our IV strategy. With better data we could generate a lagged IV that would eliminate the data of the specific firm being considered and also use data from an earlier wave. Such lagging can help generate IVs that are less likely to be endogenous. 
Delegation

Instrument for delegation

Log number of employees

Workplace operates more than 5 years

Part of a larger organization

Single independent establishment

UK owned

$\%$ of employees using computers

$\%$ of female employees

$\%$ of part-time employees

$\%$ union membership

$\%$ of employees with a fixed-term contract

$\%$ of employees with a temporary contract

$\%$ of employees who quit last year

$\%$ of employees dismissed/redundant last year

Payment by result

Merit pay

Profit-related pay

Employee share schemes

Few competitors

Many competitors

Market growing

Market mature

Market declining

$F$-statistic $\left(H_{0}\right.$ : instrument is weak)

Observations

Educational composition

Occupational composition

Largest group occupational dummies

Industry dummies

Region dummies

Missing dummies

TABLE 7

Instrumental Variable (IV) Results, Panel 2004-2011

\begin{tabular}{|c|c|c|c|}
\hline \multicolumn{2}{|c|}{ Without Workplace Fixed Effects } & \multicolumn{2}{|c|}{ With Workplace Fixed Effects } \\
\hline $\begin{array}{c}\text { First Stage } \\
\text { (1) }\end{array}$ & $\begin{array}{c}\text { Second Stage } \\
\text { (2) }\end{array}$ & $\begin{array}{c}\text { First Stage } \\
\text { (3) }\end{array}$ & \\
\hline Delegation & Training & Delegation & Training \\
\hline
\end{tabular}

$0.014(0.015)$

$0.067(0.100)$

$0.095 * *(0.045)$

$0.082 *(0.047)$

$0.037(0.043)$

$0.057 * *(0.035)$

-0.027 (0.062)

$-0.067(0.092)$

$0.040(0.101)$

$0.158(0.105)$

$-0.143(0.270)$

$-0.110(0.123)$

$-0.205(0.115)$

$0.042 *(0.024)$

$0.041(0.052)$

$0.027(0.040)$

0.037 (0.058)

$0.110(0.088)$

$0.167 *(0.095)$

$0.045 * *(0.022)$

$0.012(0.055)$

$-0.080(0.056)$

$250.90 p$ val. $=.000$

$0.105 *(0.056)$

0.009 (0.198)

$0.122(0.286)$

$0.078(0.256)$

$-0.099(0.114)$

$0.223 *(0.125)$

$0.380 *(0.214)$

$-0.396 * *(0.172)$

$0.142 *(0.078)$

$0.028(0.159)$

$-0.659(0.473)$

$-0.084(0.241)$

$-0.464 * *(0.231)$

$0.015(0.095)$

$0.196 * *(0.100)$

$0.172 * *(0.080)$

$-0.075(0.117)$

$-0.129 * *(0.065)$

$-0.187 * * *(0.071)$

$0.207 * *(0.096)$

$0.050(0.094)$

$-0.197(0.214)$

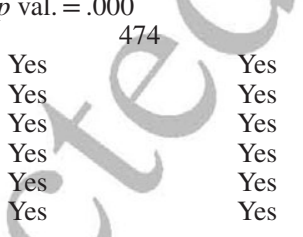

$0.092 * * *(0.006)$

$0.052(0.092) \quad 0.032(0.095)$

$0.028(0.198) \quad-0.102(0.270)$

$0.170 *(0.095)$

$0.078(0.062)$

$0.092(0.158)$

$0.020(0.012)$

$-0.011(0.067)$

$-0.156(0.225)$

$0.160(0.324)$

$0.224(0.229)$

$-0.036(0.572)$

$-0.270(0.320)$

$-0.038(0.321)$

$0.132 *(0.069)$

$0.020(0.128)$

$0.085(0.089)$

$0.019(0.085)$

$0.030(0.110)$

$0.140(0.189)$

$0.075 *(0.042)$

$0.052(0.126)$

$-0.080(0.149)$

$175.69 p$ val. $=.000$

$0.319(0.378)$

$0.454(0.372)$

$-0.458 * *(0.237)$

$0.152(0.186)$

$0.855 * *(0.401)$

$-0.775 *(0.435)$

$0.542 *(0.314)$

$0.168(0.294)$

$-0.865 *(0.479)$

$-0.095(0.370)$

$-0.262 *(0.142)$

$0.020(0.110)$

$0.275 * *(0.137)$

$0.070(0.094)$

$0.205(0.179)$

$-0.330 *(0.172)$

$-0.430 *(0.240)$

$0.072 *(0.037)$

$0.026(0.130)$

$-0.152(0.189)$

\begin{tabular}{|c|c|}
\hline Ye & Yes \\
\hline Yes & Yes \\
\hline Yes & Yes \\
\hline Yes & Yes \\
\hline No & No \\
\hline Yes & Yes \\
\hline
\end{tabular}

Notes: The instrument for delegation is the proportion of workplaces in industry cells reporting a "lot of" delegation after removing the given workplace from the industry cell. The estimation method is a 2SLS. Bootstrap standard errors using 1,000 replications with replacement and clustered at workplace cells (columns 1 and 2) and at industry cells (columns 3 and 4 ) are reported in parentheses. Estimates are weighted using workplace weights. Estimates for the other control variables are available upon request.

$* * * p<.01, * * p<.05, * p<.1$.

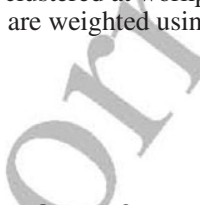

Unfortunately, we can trace firms for only two waves (2004 and 2011) so we cannot fully lag our current IV. We did estimate the 2011 training estimates using the 2004 instrument for delegation. We use the panel data from 2004 to generate industry averages that exclude the specific firm. This is used as an exogenous variable to generate the 2011 establishment-specific IV. This is presented in the first two columns of Table 8 and looks broadly similar both to the cross-sectional IV estimates in the online appendix and to the results in Table 7 suggesting that delegation is associated with 0.728 of a category increase in training. Note that by using the panel, we eliminate concerns that firms observed in 2011 might have entered in response to 2004 conditions. The identifying assumption is that past decisions by firms in this industry are exogenous to today's delegation decision by the firm in question, even though the firm in question was present in the industry in the past.

We varied this strategy by using the larger cross sections in 2004 and 2011 (which are not linked). We use the earlier cross section to aggregate industry averages that we use as excluded variables to generate a new $2011 \mathrm{IV}$. There is no individual establishment variation in these averages as the firms are not linked (the variation is by industry). We limit attention to only those 2011 establishments more than 7 years old. 
TABLE 8

Robustness Tests using Lagged Instrumental Variables

\begin{tabular}{|c|c|c|c|c|c|c|}
\hline & \multicolumn{2}{|c|}{ WERS－Panel 2011} & \multicolumn{2}{|c|}{ WERS-Cross Section 2011} & \multicolumn{2}{|c|}{ WERS-Panel 2004-2011 } \\
\hline & $\begin{array}{c}\text { First stage } \\
\text { (1) } \\
\text { Delegation }\end{array}$ & $\begin{array}{c}\text { Second Stage } \\
\text { (2) } \\
\text { Training }\end{array}$ & $\begin{array}{c}\text { First Stage } \\
\text { (3) } \\
\text { Delegation }\end{array}$ & $\begin{array}{c}\text { Second Stage } \\
\text { (4) } \\
\text { Training }\end{array}$ & $\begin{array}{c}\text { First Stage } \\
\text { (5) } \\
\text { Delegation }\end{array}$ & $\begin{array}{c}\text { Second Stage } \\
(\mathbf{6}) \\
\text { Training }\end{array}$ \\
\hline Delegation & & $\begin{array}{l}0.728 * * \\
(0.344)\end{array}$ & & $\begin{array}{l}0.452 * \\
(0.251)\end{array}$ & & $\begin{array}{l}0.559 * * * \\
(0.178)\end{array}$ \\
\hline Instrument for delegation & $\begin{array}{l}1.029 * * * \\
(0.046)\end{array}$ & & $\begin{array}{l}0.010 * * \\
(0.004)\end{array}$ & & $\begin{array}{l}0.036 * * * \\
(0.009)\end{array}$ & \\
\hline Workplace fixed effects & No & No & No & No & Yes & \\
\hline $\begin{array}{l}F \text {-statistic }\left(H_{0}:\right. \\
\text { instrument is weak) }\end{array}$ & $\begin{array}{c}501.09 \\
p \text { val. }=.000\end{array}$ & & $\begin{array}{c}12.27 \\
p \text { val. }=.012\end{array}$ & & $\begin{array}{l}14.29 \\
\text { al. }=.0\end{array}$ & \\
\hline Observations & & & & 53 & & \\
\hline Firm characteristics & Yes & Yes & Yes & Yes & Yes & Yes \\
\hline Workforce characteristics & Yes & Yes & Yes & Yes & Yes & Yes \\
\hline Occupational composition & Yes & Yes & Yes & Yes & Yes & Yes \\
\hline $\begin{array}{l}\text { Largest occupational } \\
\text { group dummies }\end{array}$ & Yes & Yes & Yes & Yes & & Yes \\
\hline Incentive pay controls & Yes & Yes & Yes & Yes & Yes & Yes \\
\hline Competition controls & Yes & Yes & Yes & Yes & Yes & Yes \\
\hline $\begin{array}{l}\text { Current market state } \\
\text { controls }\end{array}$ & Yes & Yes & Yes & Yes & Yes & Yes \\
\hline Missing dummies & Yes & Yes & Yes & & Yes & Yes \\
\hline Region dummies & Yes & Yes & Yes & Yes & No & No \\
\hline Industry dummies & Yes & Yes & No & No & Yes & Yes \\
\hline
\end{tabular}

Notes: The instrument in column 1 is lagged industry-level delegation constructed using 2004 observations only from the panel sample. We estimate this specification only for the 2011 panel data. In column 3 , the instrument is lagged industry-level delegation constructed using the 2004 cross section for those firms that have been in/operation for more than 7 years. In column 5, the instrument is composed of lagged 1998 industry-level delegation for 2004 observations, and lagged 2004 industry-level delegation for 2011 observations. The estimation method is a 2SLS. Bootstrapped standard errors using 1,000 replications with replacement are clustered at the workplace cells (columns 1-4) and at industry cells (columns 5 and 6) and are reported in parentheses. Estimates are weighted using workplace weights. Estimates for the other control variables are available upon request. In columns 5 and 6, we also add a year dummy. The number of observations for all three IV robustness checks is smaller compared to those where the instrument is contemporaneous as we lose observations when merging in lagged industry-level delegation. $* * * p<.01, * * p<.05, * p<.1$.

This eliminates firms that may have entered the industry in response to critical endogenous variables. The familiar result of delegation being associated with about a half a training category increase emerges and remains weakly significant in otherwise supportive IV estimates as shown in column 4 of Table 8.

As the estimates above cannot allow us to include establishment fixed effects, we modify our lagged IV to test a third alternative. We use the 1998 cross section of the WERS. We cannot follow individual firms from the 2004 and 2011 panel back to 1998 and so cannot link firm-level delegation between 2004 and 1998. As an alternative, we simply use the industrial aggregation across the 1998 cross section to predict individual establishment delegation in the 2004 panel. We match this by using the industrial aggregation across the 2004 cross section to predict individual establishment delegation in the 2011 panel. The results are shown in column 6 of Table 8 and also remain broadly similar to those in Table 7 . While we still cannot exclude the specific establishment from the aggregation (and so generate within industry variation in the excluded variable), we can both use a lagged measure and estimate the fixed effect on the panel.

Thus, all three of these variations in the IV strategy remain supportive. While one might think of other variations, these give no indication that the simultaneity in our initial IV spuriously generates our results.

\section{Additional Robustness Tests and Discussion}

We now undertake a series of robustness tests that bolster the empirical results. First, we identify alternative potential measures of delegation. These come from the Management Questionnaire and so provide an alternative view to that built up from the actual workers. The first asks managers: "To what extent would you say that the largest 
occupational group here have discretion over how they do their work?" "A lot," "Some," "Little," "None." We identify delegation as if the manager replies "A lot." This response is limited to the largest occupational group but we use it as the critical measure in estimates that mimic the fixedeffect IV estimate in Table 7 (columns 3 and 4). ${ }^{24}$ The IV continues to perform well and suggests that delegation using this measure is associated with a significant 0.545 of a category increase in training.

A second alternative asks managers: "To what extent would you say that the largest occupational group have involvement in decisions over how their work is organised?" "A lot," "Some," "Little," "None." Again, we identify delegation as when the manager replies "A lot." This is also limited to the largest occupational group and now emphasizes the role in decision-making of workers over their own work. While it may be only an aspect of delegation, it continues to show an association with training. In the fixed-effect IV estimates, it is associated with a significant 0.376 of a category increase in training. We have combined this measure with the previous one using principal components and used the resulting variable as a delegation measure. ${ }^{25}$ It again takes a meaningfully large coefficient in the fixed-effect IV estimates. All three of these estimates are presented in Appendix Table A2.

As a related robustness test, we return to the dependent variable on training and augment it with a follow-up question in the WERS. Those establishments which provide training to their workforce are asked the typical number of training days provided in the last year. The responses are listed in one of six categories with all those that provide no training placed in the lowest category: "No time" (1), "Less than 1 day" (2), "1 to less than 2 days" (3), "2 to less than 5 days" (4), "5 to less than 10 days" (5), and "10 days or more" (6). This provides a measure of training intensity different from the share of workers being trained. We repeat the series of estimations using this alternative measure and present

24. Pooled ordered probit and OLS panel estimates without workplace fixed effects that mimic columns 1 and 2 of Table 6 are reported in Table $\mathrm{S} 4$ in the online appendix.

25 . The eigenvalue of 1.4 between discretion and involvement exceeds the rule of thumb of 1.0. Moreover, the first principal component explains over $70 \%$ of the common variance of the two measures. In addition to principal component analysis, we also created an aggregate standardized measure of delegation by creating and adding together the associated $\mathrm{Z}$-scores. The results remain robust and are available upon request. the results with the panel IV estimates with and without workplace fixed effects in Table $9 .{ }^{26}$

The first stages continue to suggest the absence of weak instruments and the addition of the fixed-effect estimation suggests only a modestly increase in the coefficient of interest. The final column in Table 9 suggests that delegation is associated with an increase of 0.529 of a category in the days of training measure. Combining this with the earlier estimates suggests that workplaces which delegate both train a larger share of their workers and provide more training time.

We now return to the potential role of incentive schemes. Workplace incentives vary dramatically in terms of whom they target, what they reward, and how large a share of compensation they represent. The WERS provides information on whether the establishment makes use of four types of performance pay: payment by result, merit pay, profit-related pay, and employee share ownership schemes. The objective of each may well differ but it/seems likely that payment by result and merit pay tie individual effort and decisions to compensation in a very immediate way and so are designed to align the interests of workers with the firm as suggested in Appendix A. Thus, they potentially inform our earlier review of the literature, theory, and testing. If they succeed in such alignment, the investment in training can be anticipated to be greater once delegation has taken place.

We recognize that incentive schemes are likely to be highly endogenous as is delegation so we are limited in what we can credibly test. We present largely as descriptive a simple division of the sample into those firms that make use of either (or both) of the two individual incentive schemes and those that do not. We reproduce our initial fixed-effect IV estimates separately for these two groups of firms in Table 10.

The "high incentives" group of establishments that use the individual-level schemes presents the typical results. The IV strategy remains sensible (no weak instruments) and the results fit the intuition we have developed. Delegation continues to play an independent role and is associated with a significant increase of 0.524 of a training category. While the IV strategy still seems workable in the "low incentives" establishments (those that do not use the individual incentives)

26. Cross section and panel estimates of this exercise without instrumenting are available in Table S5 of the online appendix. 
TABLE 9

Alternative Dependent Variable (Days of Training), Instrumental Variable Results, Panel 2004-2011

Delegation

Instrument for delegation

Log number of employees

Workplace operates more than 5 years

Part of a larger organization

Single independent establishment

UK owned

$\%$ of employees using computers

$\%$ of female employees

$\%$ of part-time employees

$\%$ union membership

$\%$ of employees with a fixed-term contract

$\%$ of employees with a temporary contract

$\%$ of employees who quit last year

$\%$ of employees dismissed/redundant last year

Payment by result

20 Merit pay

21 Profit-related pay
Employee share schemes

Few competitors

Many competitors

Market growing

Market mature

Market declining

$F$-statistic $\left(H_{0}\right.$ : instrument is weak)

Observations

Educational composition

Occupational composition

Largest group occupational dummies

Industry dummies

Region dummies

Missing dummies
$* * * p<.01, * * p<.05, * p<.1$.

\begin{tabular}{|c|c|c|c|}
\hline \multicolumn{2}{|c|}{ Without Workplace Fixed Effects } & \multicolumn{2}{|c|}{ With Workplace Fixed Effects } \\
\hline $\begin{array}{l}\text { First Stage } \\
\text { (1) }\end{array}$ & $\begin{array}{c}\text { Second Stage } \\
\text { (2) }\end{array}$ & $\begin{array}{l}\text { First Stage } \\
(3)\end{array}$ & $\begin{array}{c}\text { Second Stage } \\
\text { (4) }\end{array}$ \\
\hline
\end{tabular}

$0.030 * * *(0.003)$

$0.025(0.021)$

$0.247 * *(0.120)$

$0.203(0.240)$

$0.113(0.242)$

$0.008(0.080)$

$0.045(0.100)$

$-0.369 * *(0.167)$

$-0.085(0.144)$

$0.057(0.139)$

$0.202(0.161)$

$-0.196(0.451)$

$-0.030(0.186)$

$-0.306(0.247)$

$0.044 *(0.026)$

$0.011(0.067)$

$0.009(0.062)$

$0.158(0.189)$

$0.105(0.134)$

$0.108(0.135)$

$0.011(0.067)$

0.027 (0.074)

$0.084(0.082)$

$145.46 p$ val. $=.000$

$0.520 * *(0.261)$

$0.281 * * *(0.062)$

$0.122(0.360)$

$0.385(0.368)$

$0.566(0.369)$

$0.099(0.210)$

$0.459 *(0.268)$

$0.521 *(0.292)$

$-0.890 * *(0.359)$

$0.253(0.362)$

$0.403(0.499)$

$-0.041(0.341)$

$-0.403(0.499)$

$-0.239(0.749)$

0.087 (0.187)

$0.351(0.182)$

$0.089(0.178)$

$0.012(0.243)$

$-0.105^{* *}(0.045)$

$-0.175 * *(0.078)$

$0.244 *(0.142)$

$0.002(0.220)$

$0.028(0.238)$

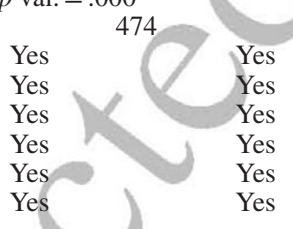

$0.045 * * *(0.004)$

$0.012(0.080) \quad 0.568 *(0.337)$

$0.090(0.270) \quad-0.795(0.600)$

$0.071(0.190)-0.555(0.564)$

$0.036(0.172) \quad 0.589(0.670)$

$0.360(0.320)-0.346(0.305)$

$0.062(0.110) \quad 0.450(0.340)$

$-0.450 *(0.249) \quad 0.859 *(0.508)$

$-0.170(0.192) \quad-0.750(0.439)$

$-0.380(0.340) \quad 0.690 *(0.350)$

$0.120(0.168)$

$0.070(0.629)$

$-0.430(0.670)$

$-0.055(0.279)$

$-0.304(0.545)$

$0.080(0.109)$

$-0.936(0.780)$

$-0.010(0.205)$

$-0.522 * *(0.258)$

$0.095(0.089)$

$0.039(0.072)$

$0.101(0.134)$

$0.240(0.230)$

$0.254(0.232)$

$0.049(0.201)$

$0.025(0.242)$

$0.015(0.130)$

$127.42 p$ val. $=.000$

$0.210(0.260)$

$0.470(0.160)$

$0.190(0.135)$

$-0.420 *(0.248)$

$-0.460 *(0.259)$

$0.310(0.410)$

$0.264(0.289)$

$-0.039(0.602)$

$\begin{array}{cc}\text { Yes } & 474 \\ \text { Yes } & \text { Yes } \\ \text { Yes } & \text { Yes } \\ \text { Yes } & \text { Yes } \\ \text { No } & \text { Yes } \\ \text { Yes } & \text { No }\end{array}$

Notes: The instrument for delegation is the proportion of workplaces in industry cells reporting a "lot of" delegation after removing the given workplace from the industry cell. The estimation method is a 2SLS. Bootstrap standard errors using 1,000 replications with replacement and clustered at workplace cells (columns 1 and 2) and at industry cells (columns 3 and 4 ) are reported in parentheses. Estimates for the other control variables are available upon request.

the coefficient is insignificant. Yet, this does not seem to be because of a large diminution in coefficient size. The point estimate admittedly drops to 0.421 but it is imprecision that seemingly causes this lack of statistical significance. In any event, it seems appropriate given our earlier description that the result should be stronger among those establishments using higher powered individual incentives.

As a final robustness check, we recognize that in some establishments owner-managers make training and delegation decisions while in other establishments, hired-managers make these decisions. While we have assumed that hired-managers act in the owner's interest, this may not be the case. To examine the empirical pattern, we divide our sample by a question that asks: "Are the controlling owners actively involved in day-to-day management of this workplace on a full-time basis?" The responses identify slightly more than one-fifth of the sample with an owner-manager and the remainder with a hired-manager. We repeat the IV exercise on the divided sample and using our original, preferred measures of training and delegation. The results for owner-manager establishments reported in columns 5 and 6 in Table 10 reveal a very large and significant role for delegation. Indeed, the implied increase of virtually a full training category stands as the largest magnitude of any of our estimates. We see this as the tight fit with our theoretical model as the delegation decision involves the owner. 
1

2

4

5

6

8

10

11

12

13

14

15

16

17

18

19

20

21

22

23

24

25

26

27

28

29

30

31

32

33

34

35

36

37

38

39

40

41

42

43

44

45

46

47

48

49

50

51

52

53

54

55

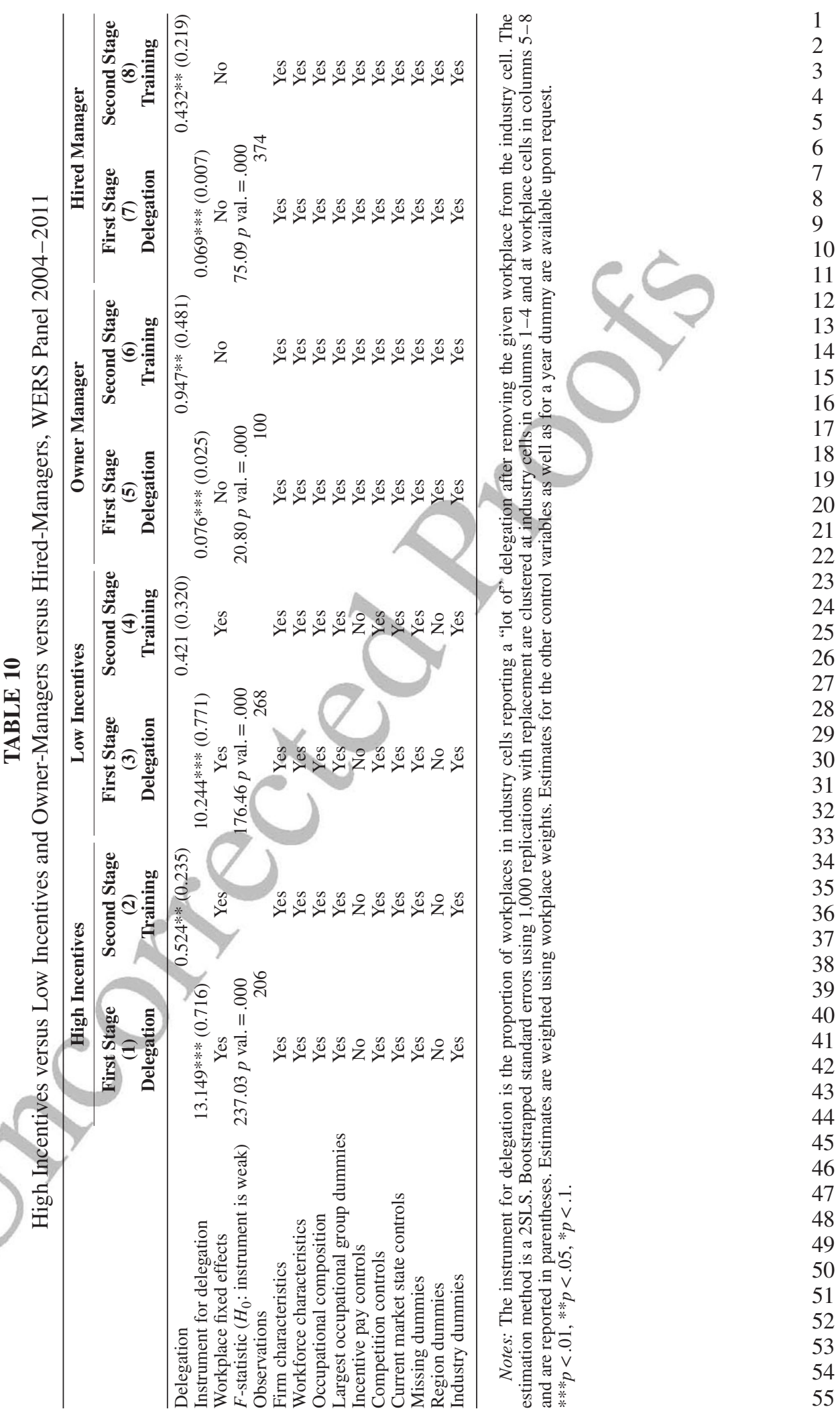


The results for the hired-manager establishments reported in columns 7 and 8 in Table 10 reveal a smaller but still positive and significant influence for delegation. The implied increase remains about one-half of a training category. This attenuation in magnitude may flow from agency problems between owners and hired-managers but a full modeling of such a three-tier hierarchy is beyond the scope of this paper. We, nonetheless, find it reassuring that the relationship remains intact as it suggests that hired-managers broadly follow the pattern of owner-managers.

These robustness exercises, together with the original results, inform the theoretical issue we initially isolated. If the firm delegates, then it suffers a loss of control but at the same time gives workers stronger effort incentives. If training reduces the marginal cost of effort, then the resulting increase in effort can justify the cost of additional training. Thus, one might anticipate that delegation generates greater employerprovided training, a result routinely returned in our empirical investigation.

\section{CONCLUSION}

In this paper, we uniquely provide a theoretical illustration and supporting empirical evidence showing that delegation increases employee training. We impose delegation or integration exogenously in our model. This can be sensible for some cases (new outside management) and as a reflection of structural differences between industries (which we exploit in our IV estimation). Yet, it will not apply to all cases. Within this framework, our nonequilibrium approach of looking at integrating and delegating firms separately provides a sensible and testable association between delegation and training. We recognize, however, that it may not help inform those interested in the exact pathways that result in the endogenous choice of delegation as part of simultaneous bundle of management practices.

We assume that employer-provided training reduces the agent's marginal effort cost of becoming informed about the payoffs of alternative investment projects. We show that delegation of decision-making authority increases training if the preferences of the firm and the worker are sufficiently congruent. When this holds, the positive effect of delegation on the worker's effort incentives dominates the loss-of-control effect and therefore the firm becomes willing to provide additional training.
We test the hypothesis of a positive relationship between delegation and training on two cross sections and an associated panel of British establishments. Our preferred measure of delegation is built up from workers within each establishment and time period. It identifies delegation when the modal response of the workers is that they have a lot of influence over their tasks. Indeed, we confirm that those establishments which delegate also provide training to a larger share of their workers. This remains true in increasingly more complete specifications, when accounting for establishment fixed effects, using alternative functional forms and in a plausible IV exercise that also controls for establishment fixed effects. The result also proves robust when altering the dependent variable to capture training intensity in number of days, and to alternative measures of delegation coming from the management questionnaire.

This result argues that those workplaces where there may be particularly good information at the level of the worker will want to delegate but that they will also want to engage in more training than those firms which do not delegate. Future "insider" econometrics might provide important insights that support or refute this argument. It would be wonderful to identify a specific establishment that devolves to workers tasks or choices previously undertaken by the management. Our survey evidence would suggest that such devolution would be accompanied by increased worker training so that superior choices would be made. Also developing insights with survey data from other countries concerning delegation and training seems a sensible next step. Furthermore, the positive interaction between incentive pay and delegation revealed by our evidence might be informing a more sophisticated theoretical model in which congruence could be affected by appropriately designed incentive schemes. The full exploration of this possibility is an additional task for future research.

Finally, we recognize limitations of our examination. Delegation is a subjective employee measure aggregated to the workplace level. While the alternative measures from the management survey provide some comfort, we recognize that an objective employee measure may provide additional insight. Also, we have not modeled or tested a multilevel hierarchy of owners, managers, and workers nor have we controlled for endogenous incentive schemes. Despite these open questions, we provide various alternative measures of delegation and confirm 
the robustness of our results to a large number of sensitivity checks, thus establishing an important contribution on which further work can build.

\section{APPENDIX A}

We extend our baseline model to incorporate incentive pay. We follow Aghion and Tirole (1997) by assuming there are only two relevant projects yielding nonnegative payoffs to $\mathrm{P}$ and $\mathrm{A}$. Specifically, $\mathrm{P}$ reaps payoff $B>0$ from one of these two projects and zero from the other. Similarly, A's benefit is $b>0$ from one of the two relevant projects and zero from the other. The degree of congruence is represented by the probability $a=\beta \in(0,1]$ that both $\mathrm{P}$ and A prefer the same project. Incentive pay is introduced through the assumption that A receives wage $w \geq 0$ if P's payoff is $B$ and zero otherwise. Suppose also that $w<B$ and $w<b$ (if the latter assumption is violated, wage incentives are so strong that A always recommends P's preferred project-i.e., incentives are aligned). In this context, the payoffs under integration and delegation become

$$
u_{p}^{n}=E \cdot(B-w)+(1-E) e \cdot a(B-w)-c(I)
$$

$$
u_{A}^{n}=E \cdot(w+a b)+(1-E) e \cdot(b+a w)-g(e, I)
$$

$$
u_{p}^{d}=e \cdot a(B-w)+(1-e) E \cdot(B-w)-c(I)
$$$$
\text { (A4) } u_{A}^{d}=e \cdot(b+a w)+(1-e) E \cdot(w+a b)-g(e, I) \text {. }
$$

In the case of integration, A chooses $e$ to maximize $u_{\mathrm{A}}^{n}$ in Equation (A2) implying the first-order condition $(1-E) \cdot(b+a w)-\partial g / \partial e=0$, which yields the interior solution:

$$
e^{*}(I, w)=((1-E)(b+a w) I) / \rho .
$$

Since $\partial e^{*} / \partial I>0$ and $\partial e^{*} / \partial w>0$, both training and monetary incentives can now be used by the employer as alternative instruments to increase A's effort contribution. Anticipating Equation (A5), P sets $w$ and $I$ so as to maximize $u_{p}^{n}$ in Equation (A1) subject to A's participation constraint. Letting $\mu_{3}$ denote the multiplier of this constraint in the associated Lagrangian $\left(L_{3}\right)$, we can write the first-order conditions:

$$
\begin{aligned}
& \partial L_{3} / \partial I=(1-E) \cdot a(B-w) \cdot\left(\partial e^{*} / \partial I\right)-c^{\prime}(I) \\
& +\mu_{3}\left(\partial u_{A}^{n}\left(e^{*}(I w), I, w\right) / \partial I\right) \leq 0,\left(\partial L_{3} / \partial I\right) \cdot I=0
\end{aligned}
$$

(A7)

$$
\partial L_{3} / \partial w=(1-E) \cdot a(B-w) \cdot\left(\partial e^{*} / \partial w\right)-\left[E+(1-E) a e^{*}\right]
$$$$
+\mu_{3}\left(\partial u_{A}^{n}\left(e^{*}(I w), I, w\right) / \partial w\right) \leq 0,\left(\partial L_{3} / \partial w\right) \cdot w=0
$$

(A8)

$$
\partial L_{3} / \partial \mu_{3}=u_{A}^{n}\left(e^{*}(I w), I, w\right)-\bar{u} \geq 0,\left(\partial L_{3} / \partial \mu_{3}\right) \cdot \mu_{3}=0
$$

where $\partial u_{A}^{n} / \partial I=(1-E)^{2}(b+a w)^{2} / 2 \rho>0$ and $\partial u_{A}^{n} / \partial w$ $=E+\left[(1-E)^{2}(b+a w) a I\right] / \rho>0$. The principal's choices of $I$ and $w$ balance the marginal benefit associated with increased worker effort against the marginal cost resulting from increased training and wage expenditures, respectively, while also taking into account that higher values of $w$ and $I$ raise A's utility (thus making it easier to satisfy the latter's participation constraint). Solving Equations (A6) to (A8) yields the intensity of training $\left(I^{n}\right)$ and wage incentives $\left(w^{n}\right)$ which can then be substituted back into Equation (A5) to derive A's effort $\left(e^{n}\right)$ for the case of integration.

Similarly, under delegation A maximizes $u_{A}^{d}$ in Equation (A4) with respect to $e$ and the first-order condition $b(1-a E)+(a-E) w-\partial g / \partial e=0$ implies the interior solution:

$$
\hat{e}(I, w)=\frac{[b(1-a E)+(a-E) w] \cdot I}{\rho} .
$$

A direct comparison of Equations (A5) and (A9) reveals that $\hat{e}(I, w)>e^{*}(I, w)$ when incentives are not aligned (i.e., for $w<b)$. Given the levels of training and wage, A is relatively more willing to provide effort under delegation (as in the case without incentive pay). Since $\partial \widehat{e} / \partial I>\partial e^{*} / \partial I$ and $\partial \widehat{e} / \partial w<\partial e^{*} / \partial w$, the positive impact of training on effort is relatively stronger under delegation but the positive impact of monetary incentives on effort is relatively stronger under integration. Moreover, for $a<E$ (i.e., when the probability that $\mathrm{P}$ and A prefer the same project is lower than the probability that $\mathrm{P}$ becomes informed) an increase in $w$ reduces A's marginal benefit from effort provision and thus weakens his incentives to become informed himself $(\partial \widehat{e} / \partial w<0)$.

Anticipating Equation (A9), P now selects the levels of $w$ and $I$ that maximize $u_{p}^{d}$ in Equation (A3) subject to A's participation constraint. If we denote by $\mu_{4}$ the multiplier of this constraint in the associated Lagrangian $\left(L_{4}\right)$, we get the following first-order conditions:

$$
\begin{aligned}
& \text { (A10) } \partial L_{4} / \partial I=(a-E)(B-w) \cdot(\partial \widehat{e} / \partial I)-c^{\prime}(I) \\
& +\mu_{4}\left(\partial u_{A}^{d}(\widehat{e}(I w), I, w) / \partial I\right) \leq 0,\left(\partial L_{4} / \partial I\right) \cdot I=0
\end{aligned}
$$

(A11)

$$
\begin{aligned}
& \partial L_{4} / \partial w=(a-E)(B-w) \cdot(\partial \widehat{e} / \partial w)-[E+(a-E) \widehat{e}] \\
& +\mu_{4}\left(\partial u_{A}^{d}(\widehat{e}(I w), I, w) / \partial w\right) \leq 0,\left(\partial L_{4} / \partial w\right) \cdot w=0
\end{aligned}
$$

(A12)

$$
\partial L_{4} / \partial \mu_{4}=u_{A}^{d}(\widehat{e}(I w), I, w)-\bar{u} \geq 0,\left(\partial L_{4} / \partial \mu_{4}\right) \cdot \mu_{4}=0 .
$$

Again, P optimally selects $I$ and $w$ by taking into account their impact on A's effort, the marginal cost resulting from increased training and wage expenditures as well as the need to keep A's participation constraint satisfied. Solving Equations (A10) to (A12) yields the levels of training $\left(I^{d}\right)$ and wage $\left(w^{d}\right)$ under delegation, which can then be used to compute worker effort $\left(e^{d}\right)$ from Equation (A9). In principle, the outcome $\left(I^{d}, w^{d}, e^{d}\right)$ can be compared to $\left(I^{n}, w^{n}, e^{n}\right)$ as already done in the main body of the article without the presence of incentive pay. While we leave such a thorough investigation of the relationship between delegation, training, and incentive pay as an open question for future research, in Table 10 of the main paper (columns 1-4), we examine the presence of highpowered incentives (individual payment by results or merit pay) or not. The results show that delegation has a large and significant impact on training only for establishments with the higher powered incentive pay. 
TABLE B1

Descriptive Statistics of All Variables

Log number of employees

\section{Log number of employees}

Workplace operates more than 5 years

Part of a larger organization

11 UK owned/controlled (predominantly UK owned $51 \%$ or more)

$\%$ of employees using computers

WERS 2004

$\%$ of female employees

$13 \%$ of part-time employees

$\%$ union membership

$15 \%$ of employees on fixed-term contract

$\%$ of employees on temporary contract

$\%$ of employees who quitted last year

$17 \%$ of employees dismissed/redundant last year

$\%$ of employees with "O" levels, grades D-E

$\%$ of employees with "O" levels, grades A-C

$\%$ of employees with "A" levels

$20 \%$ of employees with first degree (BA, BSc, BEd, etc.)

$\%$ of employees with higher degree (MSc, MA, MBA, PhD)

$\%$ of employees with other academic qualification

$\%$ of managers/senior officials

$\%$ of professional staff

$24 \%$ of technical staff

$25 \%$ of sales staff

$\%$ of operative and assembly staff

$\%$ of clerical and secretarial staff

$27 \%$ of craft and skilled staff

$28 \%$ of personal service staff

29 Largest occupational group: professional

30 Largest occupational group: technical

30 Largest occupational group: administrative

31 Largest occupational group: skilled

32 Largest occupational group: caring, leisure

33 Largest occupational group: sales

Largest occupational group: operatives

34 Payment by result

35 Merit pay

\section{Profit-related pay}

Employee share schemes (SIP, SAYE, EMI, CSOP, other)

38 Many competitors

39 Current state of the market: growing

40 Current state of the market: mature

40 Current state of the market: declining

\begin{tabular}{cc}
\hline M & SD. \\
\hline 2.640 & 0.918
\end{tabular}

WERS 2011

Panel 2004-2011

$\begin{array}{lllllll}2.640 & 0.918 & 2.667 & 0.885 & 3.403 & 0.942 & 8 \\ 0.844 & 0.363 & 0.867 & 0.340 & 0.955 & 0.207 & 9 \\ 0.589 & 0.492 & 0.508 & 0.500 & 0.552 & 0.498 & \end{array}$

$\begin{array}{lllllll}0.390 & 0.488 & 0.473 & 0.500 & 0.438 & 0.497 & 10\end{array}$

$\begin{array}{lllllll}0.861 & 0.346 & 0.874 & 0.332 & 0.894 & 0.308 & 11\end{array}$

$\begin{array}{lllllll}0.523 & 0.403 & 0.607 & 0.398 & 51.762 & 39.023 & 11 \\ 0.524 & 0.324 & 0.525 & 0.319 & 0.573 & 0.314 & 12\end{array}$

$\begin{array}{lllllll}0.524 & 0.324 & 0.525 & 0.319 & 0.573 & 0.314 & 12 \\ 0.330 & 0.302 & 0.304 & 0.301 & 0.406 & 0.312 & 13\end{array}$

$\begin{array}{lllllll}0.083 & 0.214 & 0.037 & 0.134 & 0.057 & 0.157 & 14\end{array}$

$\begin{array}{lllllll}0.040 & 0.157 & 0.066 & 0.206 & 0.047 & 0.163 & 15\end{array}$

$\begin{array}{lllllll}0.015 & 0.069 & 0.014 & 0.077 & 0.011 & 0.045 & 15 \\ 0.179 & 0.215 & 0.112 & 0.145 & 0.153 & 0.191 & 16\end{array}$

$\begin{array}{lllllll}0.179 & 0.215 & 0.112 & 0.145 & 0.153 & 0.191 & 16 \\ 0.027 & 0.069 & 0.029 & 0.069 & 0.038 & 0.094 & 17\end{array}$

$\begin{array}{lllllll}0.108 & 0.155 & 0.122 & 0.194 & 0.131 & 0.175 & 18\end{array}$

$\begin{array}{lllllll}0.197 & 0.201 & 0.325 & 0.290 & 0.251 & 0.214 & 18 \\ 0.107 & 0.150 & 0.113 & 0.156 & 0.117 & 0.169 & 19\end{array}$

$\begin{array}{lllllll}0.093 & 0.143 & 0.137 & 0.197 & 0.105 & 0.132 & 20\end{array}$

$\begin{array}{lllllll}0.093 & 0.143 & 0.137 & 0.197 & 0.105 & 0.132 & 20 \\ 0.025 & 0.088 & 0.042 & 0.113 & 0.022 & 0.063 & 21\end{array}$

$\begin{array}{lllllll}0.281 & 0.226 & 0.190 & 0.228 & 0.243 & 0.203 & 22 \\ 0.142 & 0.108 & 0.168 & 0.117 & 0.113 & 0.075 & 23\end{array}$

$\begin{array}{lllllll}0.046 & 0.132 & 0.082 & 0.182 & 0.059 & 0.142 & 23 \\ 0.057 & 0.148 & 0.094 & 0.197 & 0.062 & 0.153 & 24\end{array}$

$\begin{array}{lllllll}0.244 & 0.348 & 0.180 & 0.300 & 0.228 & 0.344 & 25\end{array}$

$\begin{array}{lllllll}0.091 & 0.212 & 0.072 & 0.191 & 0.076 & 0.187 & 25 \\ 0.131 & 0.200 & 0.112 & 0.178 & 0.112 & 0.187 & 26\end{array}$

$\begin{array}{lllllll}0.131 & 0.200 & 0.112 & 0.178 & 0.112 & 0.187 & 26 \\ 0.098 & 0.226 & 0.077 & 0.182 & 0.077 & 0.170 & 27\end{array}$

$\begin{array}{lllllll}0.098 & 0.226 & 0.077 & 0.182 & 0.077 & 0.170 & 27 \\ 0.077 & 0.232 & 0.116 & 0.280 & 0.160 & 0.315 & 28\end{array}$

$\begin{array}{lllllll}0.048 & 0.215 & 0.082 & 0.274 & 0.059 & 0.236 & 29\end{array}$

$\begin{array}{lllllll}0.063 & 0.244 & 0.116 & 0.321 & 0.079 & 0.270 & 29 \\ 0.106 & 0.308 & 0.098 & 0.298 & 0.088 & 0.284 & 30\end{array}$

$\begin{array}{lllllll}0.125 & 0.330 & 0.106 & 0.308 & 0.112 & 0.315 & 31\end{array}$

$\begin{array}{lllllll}0.098 & 0.297 & 0.144 & 0.351 & 0.193 & 0.395 & 32\end{array}$

$\begin{array}{lllllll}0.296 & 0.457 & 0.234 & 0.424 & 0.256 & 0.437 & 32 \\ 0.129 & 0.336 & 0.102 & 0.303 & 0.097 & 0.296 & 33\end{array}$

$\begin{array}{lllllll}0.280 & 0.449 & 0.194 & 0.395 & 0.217 & 0.413 & 34\end{array}$

$\begin{array}{lllllll}0.077 & 0.267 & 0.135 & 0.342 & 0.097 & 0.296 & 35\end{array}$

$\begin{array}{lllllll}0.343 & 0.475 & 0.314 & 0.464 & 0.318 & 0.466 & 36 \\ 0.120 & 0.325 & 0.091 & 0.288 & 0.122 & 0.328 & 36\end{array}$

$\begin{array}{lllllll}0.334 & 0.472 & 0.396 & 0.489 & 0.355 & 0.479 & 37\end{array}$

$\begin{array}{lllllll}0.602 & 0.490 & 0.578 & 0.494 & 0.598 & 0.491 & 38\end{array}$

$\begin{array}{lllllll}0.467 & 0.499 & 0.309 & 0.462 & 0.353 & 0.478 & 38 \\ 0.238 & 0.426 & 0.200 & 0.400 & 0.220 & 0.414 & 39\end{array}$

$\begin{array}{lllllll}0.238 & 0.426 & 0.200 & 0.400 & 0.220 & 0.414 & 39 \\ 0.136 & 0.343 & 0.152 & 0.359 & 0.153 & 0.360 & 40\end{array}$

$\begin{array}{lllllll}0.136 & 0.343 & 0.152 & 0.359 & 0.153 & 0.360 & 40 \\ 0.159 & 0.365 & 0.339 & 0.473 & 0.272 & 0.445 & 41\end{array}$

$\begin{array}{lllllll}0.130 & 0.336 & 0.111 & 0.314 & 0.079 & 0.270 & 42\end{array}$

$\begin{array}{lllllll}0.000 & 0.021 & 0.000 & 0.019 & 0.000 & 0.000 & 42 \\ 0.047 & 0.213 & 0.053 & 0.224 & 0.038 & 0.193 & 43\end{array}$

$\begin{array}{lllllll}0.047 & 0.213 & 0.053 & 0.224 & 0.038 & 0.193 & 43 \\ 0.296 & 0.457 & 0.263 & 0.441 & 0.340 & 0.474 & 44\end{array}$

$\begin{array}{lllllll}0.296 & 0.457 & 0.263 & 0.441 & 0.340 & 0.474 & 44 \\ 0.081 & 0.273 & 0.094 & 0.292 & 0.070 & 0.255 & 45\end{array}$

$\begin{array}{lllllll}0.049 & 0.216 & 0.037 & 0.190 & 0.028 & 0.165 & 46\end{array}$

$\begin{array}{lllllll}0.057 & 0.232 & 0.004 & 0.063 & 0.000 & 0.000 & 46 \\ 0.161 & 0.368 & 0.196 & 0.397 & 0.136 & 0.343 & 47\end{array}$

$\begin{array}{llllll}0.009 & 0.096 & 0.048 & 0.213 & 0.021 & 0.145\end{array}$

$\begin{array}{llllll}0.108 & 0.311 & 0.133 & 0.340 & 0.214 & 0.411\end{array}$

$\begin{array}{llllll}0.045 & 0.208 & 0.048 & 0.214 & 0.075 & 0.263\end{array}$

$\begin{array}{llllll}0.111 & 0.315 & 0.099 & 0.298 & 0.215 & 0.411\end{array}$

$\begin{array}{llllll}0.075 & 0.263 & 0.071 & 0.258 & 0.046 & 0.209\end{array}$

$\begin{array}{llllll}0.122 & 0.328 & 0.110 & 0.313 & 0.123 & 0.328\end{array}$

$\begin{array}{llllll}0.048 & 0.215 & 0.053 & 0.223 & 0.030 & 0.170\end{array}$

$\begin{array}{llllll}0.302 & 0.460 & 0.310 & 0.463 & 0.284 & 0.451\end{array}$

$\begin{array}{llllll}0.078 & 0.268 & 0.119 & 0.324 & 0.099 & 0.299\end{array}$ 
TABLE B1

Continued

\begin{tabular}{|c|c|c|c|c|c|c|}
\hline \multirow[b]{2}{*}{ Variable } & \multicolumn{2}{|c|}{ WERS 2004} & \multicolumn{2}{|c|}{ WERS 2011} & \multicolumn{2}{|c|}{ Panel 2004-2011 } \\
\hline & $M$ & $S D$. & $M$ & $S D$ & $M$ & $S D$ \\
\hline Scotland & 0.092 & 0.289 & 0.089 & 0.285 & 0.052 & 0.223 \\
\hline Owner-manager firm & 0.204 & 0.403 & 0.245 & 0.430 & 0.209 & 0.407 \\
\hline Management gives employees information about investment plans & 0.482 & 0.499 & 0.497 & 0.500 & 0.517 & 0.500 \\
\hline Training intensity: no time & 0.261 & 0.439 & 0.194 & 0.395 & 0.211 & 0.408 \\
\hline Training intensity: less than 1 day & 0.050 & 0.218 & 0.047 & 0.211 & 0.065 & 0.247 \\
\hline Training intensity: 1 to less than 2 days & 0.193 & 0.395 & 0.199 & 0.400 & 0.239 & 0.427 \\
\hline Training intensity: 2 to less than 5 days & 0.273 & 0.445 & 0.334 & 0.472 & 0.255 & 0.436 \\
\hline Training intensity: 5 to less than 10 days & 0.114 & 0.318 & 0.128 & 0.334 & 0.132 & 0.338 \\
\hline Training intensity: 10 days or more & 0.108 & 0.310 & 0.095 & 0.294 & 0.096 & 0.295 \\
\hline Dummy for missing firm age & 0.042 & 0.200 & 0.026 & 0.160 & 0.013 & 0.113 \\
\hline Dummy for missing \% union membership & 0.039 & 0.193 & 0.049 & 0.215 & 0.073 & 0.260 \\
\hline Dummy for missing $\%$ of employees on fixed-term contract & 0.009 & 0.095 & 0.000 & 0.000 & 0.000 & 0.000 \\
\hline Dummy for missing $\%$ of employees on temporary contract & 0.006 & 0.077 & 0.000 & 0.021 & 0.000 & 0.013 \\
\hline Dummy for missing $\%$ of employees quitted last year & 0.040 & 0.197 & 0.023 & 0.149 & 0.034 & 0.181 \\
\hline Dummy for missing $\%$ of employees dismissed/redundant last year & 0.041 & 0.199 & & 0.138 & 0.022 & 0.147 \\
\hline Observations & & & & & & \\
\hline
\end{tabular}

Management gives employees information about investment plans

$\begin{array}{lll}0.482 & 0.499\end{array}$

0.497

0.430

0.407

Notes: Means and standard deviations for each variable are reported for the two cross sections and the panel samples. Means are weighted using workplace weights. Means for variables with missing observations are estimated on nonmissing observations.

TABLE B2

Instrumental Variable (IV) Results: Panel Data 2004-2011, Alternative Measures of Delegation

\begin{tabular}{|c|c|c|c|c|c|c|}
\hline & \multirow{2}{*}{\multicolumn{2}{|c|}{ Discretion }} & \multirow{2}{*}{\multicolumn{2}{|c|}{ Involvement }} & \multirow{2}{*}{\multicolumn{2}{|c|}{$\begin{array}{l}(5) \\
\text { Principal Component } \\
\text { Analysis }\end{array}$}} \\
\hline & & & & & & \\
\hline & \multicolumn{2}{|c|}{$\begin{array}{l}\text { With Workplace } \\
\text { Fixed Effects }\end{array}$} & \multicolumn{2}{|c|}{$\begin{array}{l}\text { With Workplace } \\
\text { Fixed Effects }\end{array}$} & \multicolumn{2}{|c|}{$\begin{array}{l}\text { With Workplace } \\
\text { Fixed Effects }\end{array}$} \\
\hline & $\begin{array}{l}\text { First Stage } \\
\text { Delegation }\end{array}$ & $\begin{array}{c}\text { Second Stage } \\
\text { Training }\end{array}$ & $\begin{array}{l}\text { First Stage } \\
\text { Delegation }\end{array}$ & $\begin{array}{l}\text { Second Stage } \\
\text { Training }\end{array}$ & $\begin{array}{l}\text { First Stage } \\
\text { Delegation }\end{array}$ & $\begin{array}{l}\text { Second Stage } \\
\text { Training }\end{array}$ \\
\hline Delegation & & $\begin{array}{l}0.545^{* *} \\
(0.247)\end{array}$ & & $\begin{array}{l}0.376^{* *} \\
(0.189)\end{array}$ & & $\begin{array}{l}0.265^{* *} \\
(0.117)\end{array}$ \\
\hline Instrument for delegation & $\begin{array}{c}15.883 * * * \\
(2.348)\end{array}$ & & $12.246 * * *$ & & $9.324 * * * *$ & \\
\hline $\begin{array}{l}F \text {-statistic }\left(H_{0} \text { : }\right. \\
\text { instrument is weak) }\end{array}$ & $\begin{array}{l}128.44 \\
p \text { val. }=.000\end{array}$ & & $\begin{array}{c}142.21 \\
p \text { val. }=.000\end{array}$ & & $\begin{array}{l}95.42 \\
p \text { val. }=.000\end{array}$ & \\
\hline Observations & 474 & & 474 & 474 & 474 & 474 \\
\hline Industry dummies & Yes & Yes & Yes & Yes & Yes & Yes \\
\hline Region dummies & No & No & No & No & No & No \\
\hline Workplace characteristics & Yes & Yés & Yes & Yes & Yes & Yes \\
\hline Workforce characteristics & Yes & Yes & Yes & Yes & Yes & Yes \\
\hline Occupational composition & Yes & Yes & Yes & Yes & Yes & Yes \\
\hline $\begin{array}{l}\text { Largest occupational } \\
\text { group dummies }\end{array}$ & & Yes & Yes & Yes & Yes & Yes \\
\hline PRP dummies & & Yes & Yes & Yes & Yes & Yes \\
\hline Competition dummies & Yes & Yes & Yes & Yes & Yes & Yes \\
\hline Market state dummies & Yes & Yes & Yes & Yes & Yes & Yes \\
\hline Missing dummies & & Yes & Yes & Yes & Yes & Yes \\
\hline
\end{tabular}

Notes: The dependent variable is the proportion of experienced employees in the largest occupational group who have been given time off from their normal daily work to undertake training over the last 12 months. In columns 1 and 2 , delegation is measured from the Management Questionnaire from the following question: "Using the scale on this card, to what extent would you say that the largest occupational group here have discretion over how they do their work?" "A lot," "Some," Little," "None." We code as delegation if managers replied "A lot." In columns 3 and 4, delegation is measured from the management questionnaire from the following question: "Using the scale on this card, to what extent would you say that the largest occupational group have involvement in decisions over how their work is organized?" "A lot," "Some," "Little," "None." We code as delegation if managers replied "A lot." In columns 5 and 6, delegation is constructed using the first principal component of discretion and involvement. For reasons of brevity, we only present estimates of the variable of interest. Other controls are those shown in column 4 of Table 3 in the main paper, as well as a year dummy. The estimates for the rest of the covariates are available upon request. Bootstrap standard errors using 1,000 replications with replacement and clustered at industry cells are reported in parentheses. Estimates are weighted using workplace weights. $* * * p<.01, * * p<.05, * p<.1$. 


\section{REFERENCES}

Acemoglu, D., and J. S. Pischke. "Why Do Firms Train? Theory and Evidence." The Quarterly Journal of Economics, 113, 1998, 79-119.

. "Beyond Becker: Training in Imperfect Labour Markets." Economic Journal, 109, 1999, F112-42.

Aghion, P., N. Bloom, and J. VanReenen. "Incomplete Contracts and the Internal Organization of Firms." The Journal of Law, Economics, \& Organization, 30, 2014, 37-63.

Aghion, P., and J. Tirole. "Formal and Real Authority in Organizations." Journal of Political Economy, 105, 1997, $1-29$.

Allgulin, M., and T. Ellingsen. "Monitoring and Pay." Journal of Labor Economics, 20, 2002, 201-16.

Arulampalam, W., and A. Booth. "Training and Labour Market Flexibility: Is There a Trade-Off?" British Journal of Industrial Relations, 36, 1998, 521-36.

Baker, G., R. Gibbons, and K. Murphy. "Informal Authority in Organizations." Journal of Law, Economics, and Organization, 15, 1999, 56-73.

Barron, J. M., M. C. Berger, and D. A. Black. "How Well Do We Measure Training." Journal of Labor Economics, 15, 1997, 507-28.

Bester, H., and D. Krahmer. "Delegation and Incentives." The RAND Journal of Economics, 39, 2008, 664-82.

Bilanakos, C., C. P. Green, J. S. Heywood, and N. Theodoropoulos. "Do Dominant Firms Provide More Training?" Journal of Economics and Management Strategy, 26, 2017, 67-95.

Black, D. A., B. J. Noel, and Z. Wang. "On-the-Job Training Establishment Size, and Firm Size: Evidence for Economies of Scale in the Production of Human Capital." Southern Economic Journal, 66, 1999, 82-100.

Bloom, N., C. Genakos, R. Sadun, and J. VanReenen. "Management Practices across Firms and Countries." Academy of Management Perspectives, 26, 2012a $12-33$.

Bloom, N., R. Sadun, and J. VanReenen. "Americans Do IT Better: US Multinationals and the Productivity Miracle." American Economic Review, 102, 2012b, 167-201.

Boedker, C., R. Vidgen, K. Meahgher, J. Cogin, J. Mouritsen, and J. M. Runnnalls Leadership, Culture and Management Practices of High Performing Workplaces in Australia: High Performing Workplace Index. Sydney: Society for Knowledge Economics, 2011.

Boheim, R., and A. Booth. "Trade Union Presence and Employer-Provided Training in Greater Britain." Industrial Relations, 43, 2004, 520-44.

Bolton, P., and M. Dewatripont "Authority in Organizations: A Survey," in The Handbook of Organizational Economics, edited by R. Gibbons and J. Roberts. Princeton, NJ: Princeton University Press, 2013.

Booth, A., and M. Bryan. "Testing Some Predictions of Human Capital Theory: New Training Evidence from Britain," The Review of Economics and Statistics, 87, 2005, 391-4.

Booth, A."Job Related Formal Training: Who Receives It and What Is Worth for?" Oxford Bulletin of Economics and Statistics, 53, 1991, 281-94.

Brunello, G., and F. Gambarotto. "Do Spatial Agglomeration and Local Labor Market Competition Affect EmployerProvided Training? Evidence from the UK." Regional Science and Urban Economics, 37, 2007, 1-21.

Caroli, E., N. Greenan, and D. Guellec. "Organizational Change and Skill Accumulation." Industrial and Corporate Change, 10, 2001, 481-506.

Chaplin, J., J. Mangla, S. Purdon, and C. Airey. "The Workplace Employment Relations Survey 2004.” Technical
Report (Cross Section and Panel Surveys), National Centre for Social Research, London, 2005.

Colombo, M., and M. Delmastro. "Delegation of Authority in Business Organizations: An Empirical Test.” Journal of Industrial Economics, 52, 2004, 53-80.

De Paola, M., and V. Scoppa. "Organizational Design, Project Selection, and Incentives." Journal of Institutional and Theoretical Economics, 162, 2006, 424-49.

De Varo, J., and F. A. Kurtulus. "An Empirical Analysis of Risk, Incentives and the Delegation of Worker Authority." Industrial and Labor Relations Review, 64, 2010, 641-61.

De Varo, J., and S. Prasad. "The Relationship between Delegation and Incentives across Occupations: Evidence and Theory." The Journal of Industrial Economics, 63 2015, 279-312.

Dessein, W. "Authority and Communication in Organizations." Review of Economic Studies, 69, 2002, 811-38.

Dustmann, C., and U. Schönberg. "Training and Union Wages." The Review of Economics and Statistics, 91, 2007, 363-76.

Fisman, R., and J. Svensson. "Are Corruption and Taxation Really Harmful to Growth? Firm Level Evidence." Journal of Development Economics, 83, 2007, 63-75.

Foss, N. J., and K. Laursen. "Performance Pay and Delegation under Uncertainty and Innovativeness: An Empirical Investigation." Journal of Economic Behavior \& Organization, 58, 2005, 246-76.

Garicano, L., and L. Rayo. "Why Organizations Fail: Models and Cases." Journal of Economic Literature, 54, 2016, 137-92.

Green, F., and L. Zanchi. "Trends in the Training of Male and Female Workers in the United Kingdom." British Journal of Industrial Relations, 35, 1997, 635-44.

Green, F., S. Machin, and D. Wilkinson. "Trade Unions and Training Practices in British Workplaces." Industrial and Labor Relations Review, 52, 1999, 179-95.

Greene, W. H. "Estimating Econometric Models with Fixed Effects." Discussion Paper, Department of Economics, Stern School of Business, New York University, 2001.

Grossman, S. J., and O. D. Hart. "The Costs and Benefits of Ownership: A Theory of Vertical and Lateral Integration." Journal of Political Economy, 94, 1986, 691-719.

Hart, O. D., and B. Holmstrom. "A Theory of Firm Scope." The Quarterly Journal of Economics, 125, 2010, 483-513.

Hart, O. D., and J. Moore. "Property Rights and the Nature of the Firm." Journal of Political Economy, 98, 1990, $1119-58$.

Hilbe, J. M., and W. H. Green "Count Regression Models," in Handbook of Statistics (Epidemiology and Medical Statistics), Vol. 27, Chapter 7, edited by C. R. Rao, J. P. Miller and D. C. Rao 2008, 210-52.

Holmstrom, B. "On the Theory of Delegation," in Bayessean Models in Economics Theory, edited by M. Boyer and R. Kihlstrom. New York: North Holland, 1984.

Holtmann, A. G., and T. L. Idson. "Employer Size and on the Job Training Decisions." Southern Economic Journal, 58, 1991, 339-55.

Ichniowski, C., K. Shaw, and G. Prennushi. "The Effects of Human Resource Management Practices on Productivity." American Economic Review, 87, 1997, 291-313.

Itoh, H., T. Kikutani, and O. Hayashida. "Complementarities among Authority, Accountability and Monitoring. Evidence from Japanese Business Groups." Journal of the Japanese and International Economies, 22, 2008, 207-28.

Jensen, M., and W. Meckling "Specific and General Knowledge and Organizational Structure," in Contract Economics, edited by L. Werin and H. Wijkander. Oxford, England: Blackwell Publishers, 1992. 
Katz, E., and A. Ziderman. "Investment in General Training: The Role of Information and Labour Mobility." The Economic Journal, 100, 1990, 1147-58.

Kersley, B., A. Carmen, J. Forth, A. Bryson, H. Bewley, G. Dix, and S. Oxenbridge Inside the Workplace: Findings from the 2004 Workplace Employment Relations Survey. Oxford: Routledge, Taylor \& Francis Group, 2006.

Krueger, A. B. "How Computers Have Changed the Wage Structure: Evidence from Micro Data, 1984-1989." The Quarterly Journal of Economics, 108, 1993, 33-60.

Lai, T.-K., and T. Ng. "The Impact of Product Market Competition on Training Provision: Evidence from Canada." The Canadian Journal of Economics, 47, 2014, 856-88.

Lo, D. (. H.-F.)., W. Dessein, M. Ghosh, and F. Lafontaine. "Price Delegation and Performance Pay: Evidence from Industrial Sales Forces." Journal of Law, Economics, and Organization, 32, 2016, 508-44.

Manning, A. Monopsony in Motion: Imperfect Competition in Labor Markets. Princeton, NJ; Oxford: Princeton University Press, 2003.

Meagher, K. J., and A. Wait. "Delegation of Decisions about Change in Organizations: The Roles of Competition, Trade, Uncertainty, and Scale." The Journal of Law, Economics, \& Organization, 30, 2014, 709-33.

Murphy, K. M., and R. P. Topel. "Estimation and Inference in Two-Step Econometric Models.” Journal of Business \& Economic Statistics, 3, 1985, 370-9.

Nagar, V. "Delegation and Incentive Compensation." The Accounting Review, 77, 2002, 379-95.

Osterman, P. "How Common Is Workplace Transformation and Who Adopts It?" Industrial and Labor Relations Review, 47, 1994, 173-88.

Pagan, A. "Econometric Issues in the Analysis of Regressions with Generated Regressors." International Economic Review, 25, 1984, 221-47.
Rajan, G. R., and J. Wulf. "The Flattening Firm: Evidence from Panel Data on the Changing Nature of Corporate Hierarchies." The Review of Economics and Statistics, 88, 2006, 759-73.

Stein, J. "Information Production and Capital Allocation: Decentralized versus Hierarchical Firms." The Journal of Finance, 57, 2002, 1891-921.

Van Wanrooy, B., H. Bewley, A. Bryson, J. Forth, S. Freeth, L. Stokes, and S. Wood. "The 2011 Workplace Employment Relations Survey: First Findings.” 2013. https:// www.gov.uk/government/uploads/system/uploads/ attachment_data/file/210103/13-1010-WERS-firstfindings-report-third-edition-may-2013.pdf

Zabojnik, J. "Centralized and Decentralized Decision Making in Organizations." Journal of Labor Economics, 20, $2002,1-22$.

\section{SUPPORTING INFORMATION}

Additional Supporting Information may be found in the online version of this article:

Appendix S1.

Table S1. Panel Data 2004-2011: Alternative Functional Forms

Table S2. Instrumental Variable (IV) Results, Cross Sections

Table S3. A Parsimonious IV Specification

Table S4. Panel Data 2004-2011: Alternative Measures of Delegation

Table S5. Alternative Dependent Variable (Days of Training) 